\title{
Mutations in a Single Signaling Pathway Allow Cell Growth in Heavy Water
}

Kampmeyer, Caroline; Johansen, Jens V; Holmberg, Christian; Karlson, Magnus; Gersing, Sarah K; Bordallo, Heloisa N; Kragelund, Birthe B; Lerche, Mathilde Hauge; Jourdain, Isabelle; Winther, Jakob R Total number of authors:

11

Published in:

ACS Synthetic Biology

Link to article, DOI:

10.1021/acssynbio.9b00376

Publication date:

2020

Document Version

Peer reviewed version

Link back to DTU Orbit

Citation (APA):

Kampmeyer, C., Johansen, J. V., Holmberg, C., Karlson, M., Gersing, S. K., Bordallo, H. N., Kragelund, B. B., Lerche, M. H., Jourdain, I., Winther, J. R., \& Hartmann-Petersen, R. (2020). Mutations in a Single Signaling Pathway Allow Cell Growth in Heavy Water. ACS Synthetic Biology, 9(4), 733-748.

https://doi.org/10.1021/acssynbio.9b00376

\section{General rights}

Copyright and moral rights for the publications made accessible in the public portal are retained by the authors and/or other copyright owners and it is a condition of accessing publications that users recognise and abide by the legal requirements associated with these rights.

- Users may download and print one copy of any publication from the public portal for the purpose of private study or research.

- You may not further distribute the material or use it for any profit-making activity or commercial gain

- You may freely distribute the URL identifying the publication in the public portal 


\section{Mutations in a single signaling pathway allow growth on a different solvent than water}

Caroline Kampmeyer ${ }^{1}$, Jens V. Johansen ${ }^{2}$, Christian Holmberg ${ }^{1}$, Magnus Karlson ${ }^{3}$, Sarah K. Gersing ${ }^{1}$, Heloisa N. Bordallo ${ }^{4}$, Birthe B. Kragelund ${ }^{1}$, Mathilde H. Lerche ${ }^{3}$, Isabelle Jourdain ${ }^{5}$, Jakob R. Winther ${ }^{1}$ and Rasmus Hartmann-Petersen ${ }^{1, *}$

Running title: The cellular response to solvent replacement

Keywords: $\mathrm{D}_{2} \mathrm{O}$, deuterium oxide, yeast, cell stress, protein folding, cytokinesis, deuteration

1: The Linderstrøm-Lang Center, Department of Biology, University of Copenhagen, Ole Maaløes Vej 5, DK-2200 Copenhagen, Denmark.

2: Biotech Research and Innovation Centre, University of Copenhagen, Ole Maaløes Vej 5, DK-2200, Copenhagen, Denmark.

3: Technical University of Denmark, Department of Electrical Engineering, Ørsted Plads, Bld. 349, DK-2800 Kgs. Lyngby, Denmark.

4: Niels Bohr Institute, University of Copenhagen, Universitetsparken 5, DK-2100 Copenhagen, Denmark.

5: College of Life and Environmental Sciences, University of Exeter, Geoffrey Pope Building, Stocker Road, Exeter EX4 4QD, United Kingdom.

*Corresponding author: R.H.-P. (rhpetersen@bio.ku.dk). 


\section{Abstract}

Since life is completely dependent on water, it is difficult to gauge the impact of solvent change. To analyze the role of water as a solvent in biology, we replaced water with heavy water $\left(\mathrm{D}_{2} \mathrm{O}\right)$, and investigated the biological effects by a wide range of techniques, using the fission yeast Schizosaccharomyces pombe as model organism. We show that high concentrations of $\mathrm{D}_{2} \mathrm{O}$ lead to altered glucose metabolism, growth retardation, and inhibition of meiosis. However, mitosis and overall cell viability were only slightly affected. After prolonged incubation in $\mathrm{D}_{2} \mathrm{O}$, cells displayed gross morphological changes, thickened cell walls as well as aberrant septa and cytoskeletal organization. RNA sequencing revealed that $\mathrm{D}_{2} \mathrm{O}$ causes a strong downregulation of most tRNAs and triggers activation of the general stress response pathway. Genetic screens identified several $\mathrm{D}_{2} \mathrm{O}$ sensitive mutants, while mutants compromised in the cell integrity pathway, including the protein kinase genes pmk1, mkh1, pek1 and pck2, that control cell wall biogenesis, were more tolerant to $\mathrm{D}_{2} \mathrm{O}$. We speculate that $\mathrm{D}_{2} \mathrm{O}$ affects the phospholipid membrane or cell wall glycans causing an activation of the cell integrity pathway. In conclusion, the effects of solvent replacement are pleiotropic but the $\mathrm{D}_{2} \mathrm{O}$-triggered activation of the cell integrity pathway and subsequent increased deposition of cell wall material and septation problems appear most critical for the cell growth defects. 


\section{Introduction}

Although in principle life might be possible in other solvents such as ammonia or formamide [1], life, as we know it, is completely dependent on water. As solvent, water provides a liquid phase that facilitates chemical reactions by allowing reactants to encounter each other, but also ensures that various biomolecules, organelles and tissues can maintain a functional structure. Importantly, water also actively partakes in chemical reactions as a reactant (e.g. hydrolysis) or as a product (e.g. condensation). To some degree, organic solvents, such as DMSO, fulfill some of these requirements. However, these solvents are often toxic already at low concentrations [2] and do not generally engage in chemical reactions.

${ }^{1} \mathrm{H}$ is by far the most abundant isotope of hydrogen and while ${ }^{2} \mathrm{H}$ or deuterium (D) and $\mathrm{D}_{2} \mathrm{O}$ (heavy water) are fairly similar to ${ }^{1} \mathrm{H}$ and light water, respectively, the chemical effects of isotope substitution is far stronger than seen for most other chemical elements [3]. Thus, when substituting water as solvent, there are very significant differences between light and heavy water. Both compounds are non-radioactive, but $\mathrm{D}_{2} \mathrm{O}$ is denser ( 1.1 vs. $\left.1.0 \mathrm{~g} \mathrm{~mL}^{-1}\right)$ and more viscous (1.25 vs. $1.00 \mathrm{mPa}$ s at 20 $\left.{ }^{\circ} \mathrm{C}\right)$ than $\mathrm{H}_{2} \mathrm{O}$. It has a higher melting point $\left(3.82\right.$ vs. $\left.0{ }^{\circ} \mathrm{C}\right)$ as well as a higher boiling point (101.4 vs. $100^{\circ} \mathrm{C}$ ), consistent with the deuterium bonds in $\mathrm{D}_{2} \mathrm{O}$ being stronger than the corresponding hydrogen bonds in $\mathrm{H}_{2} \mathrm{O}$. Accordingly, $\mathrm{D}_{2} \mathrm{O}$ is known to influence the conformational and functional properties of proteins and other macromolecules in vitro $[4,5]$.

Although the natural abundance of deuterium in water is less than $0.02 \%$, it is interesting to study the cellular effects of $\mathrm{D}_{2} \mathrm{O}$ because its unique properties allow for a complete solvent replacement, and may therefore highlight the importance of the biophysical properties of $\mathrm{H}_{2} \mathrm{O}$ as solvent for biological processes. However, the cellular consequences of exchanging $\mathrm{H}_{2} \mathrm{O}$ with $\mathrm{D}_{2} \mathrm{O}$ have so far not been systematically addressed. When $\mathrm{D}_{2} \mathrm{O}$ replaces $\mathrm{H}_{2} \mathrm{O}$ in the cell, it affects reaction kinetics and the structure of macromolecules, giving rise to the so-called "solvent isotope effect" [5]. However, the 
deuterium atoms in $\mathrm{D}_{2} \mathrm{O}$ can also metabolically replace hydrogen atoms in biomolecules. When deuterium is metabolically incorporated into proteins and other biomolecules, the properties of C-D bonds in particular, which do not readily exchange with $\mathrm{H}$, become important. Thus, $\mathrm{C}-\mathrm{D}$ bonds may affect the structure and dynamics of macromolecules, resulting in the "deuterium isotope effect" [5]. Since hydrogen is much lighter than other biologically-relevant elements, the proportional isotope effects of deuterium are significantly stronger than e.g. those of ${ }^{13} \mathrm{C}\left(\mathrm{vs} .{ }^{12} \mathrm{C}\right)$ or ${ }^{18} \mathrm{O}\left(\mathrm{vs} .{ }^{16} \mathrm{O}\right)[3]$. Soon after its discovery and large-scale manufacture, the first biological effects of $\mathrm{D}_{2} \mathrm{O}$ were described (for review see [5]). Today we know that small amounts of $\mathrm{D}_{2} \mathrm{O}$ are not toxic [6], and $\mathrm{D}_{2} \mathrm{O}$ can be used to measure the metabolic rate in humans [7,8], or as a tracer for compliance in drug trials [9]. However, biological studies on $\mathrm{D}_{2} \mathrm{O}$ have shown that at high levels ( $>25 \%$ of body weight) $\mathrm{D}_{2} \mathrm{O}$ is toxic to animals and causes sterility [5]. In addition, heavy water has been reported to affect the period of circadian oscillations in Drosophila [10], while studies in rodents have shown that high $\mathrm{D}_{2} \mathrm{O}$ concentrations causes anemia and early death $[11,12]$. In plant and animal cells, $\mathrm{D}_{2} \mathrm{O}$ inhibits mitosis $[13,14]$, which may be linked to increased microtubule stabilization $[15,16]$. Bacteria can adapt to grow in $100 \% \mathrm{D}_{2} \mathrm{O}$ [17-19], while budding yeast cells can tolerate up to $90 \%$ heavy water [20]. However, heavy water sensitivity has been described as a conditional phenotype in budding yeast and a $\mathrm{D}_{2} \mathrm{O}$ hypersensitive mutant in the ASP5 gene, encoding a cytosolic aspartate aminotransferase involved in nitrogen metabolism, has been isolated [20]. Recently, it was shown that the amount of deuterated metabolites decline in yeast cells during aging, and supplementing the growth medium with $50 \% \mathrm{D}_{2} \mathrm{O}$ increases the lifespan [21], presumably by slowing the metabolism. As a solvent, $\mathrm{D}_{2} \mathrm{O}$ has been reported to marginally increase the heat stability of macromolecules [4], including double stranded DNA [22, 23] and some proteins [24-26]. In addition, $\mathrm{D}_{2} \mathrm{O}$ can function as a chemical chaperone for misfolded proteins [27]. However, on the cellular level, $\mathrm{D}_{2} \mathrm{O}$ may lead to a decrease in heat tolerance [28]. 
91 Here, we analyzed the biochemical and physiological effects of $\mathrm{D}_{2} \mathrm{O}$ on the fission yeast 92 Schizosaccharomyces pombe, a well characterized and genetically tractable eukaryotic model 93 organism [29]. We found that the solvent exchange effect rather than the isotope effect caused a 94 strongly reduced growth rate at high concentrations of $\mathrm{D}_{2} \mathrm{O}$. Although the overall cell viability 95 remained largely unaffected, $\mathrm{D}_{2} \mathrm{O}$ inhibited the glucose metabolism and caused gross morphological 96 changes, thickened cell walls and abnormal cell septation. Transcriptomic analyses revealed that $\mathrm{D}_{2} \mathrm{O}$ 97 triggered differential expression of numerous genes, including a strong reduction of tRNAs, and 98 activation of the general stress response pathway. Genetic screens identified several $\mathrm{D}_{2} \mathrm{O}$ sensitive 99 mutants, including a deletion in the rga7 GTPase activating protein (GAP). Surprisingly, mutants in 100 pck2, mkh1, pek1, and pmk1, that encode kinases of the cell integrity pathway, which controls cell 101 wall biogenesis, were tolerant to the solvent exchange. 


\section{Results}

Dramatically reduced growth of S. pombe exposed to high concentrations of $\mathrm{D}_{2} \mathrm{O}$

The $\mathrm{D}_{2} \mathrm{O}$ was purchased as $99.8 \% \mathrm{D}_{2} \mathrm{O} / 0.2 \% \mathrm{H}_{2} \mathrm{O}$. For simplicity, when all regular deionized water in the growth medium was replaced with the $99.8 \%$ pure $\mathrm{D}_{2} \mathrm{O}$ we will in the following refer to these experiments as performed at $100 \% \mathrm{D}_{2} \mathrm{O}$, and similarly for experiments conducted at lower $\mathrm{D}_{2} \mathrm{O}$ concentrations. Importantly, the other components (e.g. glucose) in the media were, unless stated otherwise, not deuterated. Hence, even in our $100 \% \mathrm{D}_{2} \mathrm{O}$ media some non-exchangeable protons are available to the cells and will be incorporated in biomolecules.

As a first step in our cell physiological analyses of $\mathrm{D}_{2} \mathrm{O}$, we followed the growth of wild type $S$. pombe cells exposed to different concentrations of $\mathrm{D}_{2} \mathrm{O}$. Pre-cultures, prepared in standard rich medium (YES medium with $\mathrm{H}_{2} \mathrm{O}$ ), were washed and diluted with YES medium with $100 \%, 75 \%$, $50 \%, 25 \%$ and $0 \%$ heavy water and growth was monitored by measuring the turbidity of the cultures. At $\mathrm{D}_{2} \mathrm{O}$ concentrations $>50 \%$, the cell growth rate was strongly reduced (Fig. $1 \mathrm{AB}$ ) and the onset of growth inhibition occurred rapidly, already within the first generation (Fig. 1C). The effect was dosage dependent leading to an increase in doubling time from approximately 2.5 hours in $0 \% \mathrm{D}_{2} \mathrm{O}$ to around 7 hours at $100 \% \mathrm{D}_{2} \mathrm{O}$ (Fig. 1B). The observed growth retardation was not caused by cell death, since cell viability was only marginally affected after prolonged incubation with $\mathrm{D}_{2} \mathrm{O}$ (Fig. 121 1D).

122 Since bacteria can be adapted to growth at $100 \% \mathrm{D}_{2} \mathrm{O}[17,19]$, we tested if pre-incubating the cells 123 with different amounts of $\mathrm{D}_{2} \mathrm{O}$ would allow for increased growth rates in the presence of $\mathrm{D}_{2} \mathrm{O}$ on solid 124 rich medium. However, this was not the case for fission yeast. Hence, for all tested pre-incubations no changes in growth were observed (Fig. 1E), although we noted that when grown on solid media, wild type cells eventually formed colonies even at $100 \% \mathrm{D}_{2} \mathrm{O}$. 
The observed effects of $\mathrm{D}_{2} \mathrm{O}$ may be caused by either incorporating deuterium into macromolecules or by replacing the solvent $\left(\mathrm{H}_{2} \mathrm{O}\right)$ with $\mathrm{D}_{2} \mathrm{O}$ or by a combination of the above. Thus, we compared the growth of cells on media prepared with normal glucose or deuterated glucose (glucose-C-d 7 ). On rich media, there was no obvious effect of exchanging glucose with deuterated glucose (Fig. 1F). Since amino acids are plentiful in this medium, significant protein deuteration of non-solventexchangeable protons is not expected. On minimal medium, a slight growth inhibitory effect was observed (Fig. 1F). Since glucose here also serves as a carbon source for amino acid synthesis, the slightly reduced growth is, at least in part, likely to be ascribed to deuteration of proteins and other biomolecules. However, since the effect of deuterated glucose is minor, the observed effect of $\mathrm{D}_{2} \mathrm{O}$ is mainly caused by the solvent replacement. Accordingly, the growth retardation observed on media prepared with both deuterated glucose and $\mathrm{D}_{2} \mathrm{O}$ were similar to that observed on media with hydrogenated (normal) glucose and $\mathrm{D}_{2} \mathrm{O}$ (Fig. 1F). We therefore conclude that the growth inhibitory effect of $\mathrm{D}_{2} \mathrm{O}$ largely can be attributed to the solvent isotope effect rather than an effect of deuteriuminduced malfunction of various biomolecules.

\section{$\mathrm{D}_{2} \mathrm{O}$ causes gross morphological changes, increased cell wall thickness and aberrant cell septation}

The reduced cell growth was accompanied by an elongated and swollen cell morphology, which was more apparent after prolonged incubation in $\mathrm{D}_{2} \mathrm{O}$ (Fig. 2A). Cell septation was analyzed by calcofluor staining. This revealed a clear dosage-dependent septation defect, which appeared gradually upon shifting the cells to $\mathrm{D}_{2} \mathrm{O}$ medium. Hence, after 5 hours in the exponential growth phase, roughly $20 \%$ of the cells in $0 \% \mathrm{D}_{2} \mathrm{O}$ were septated, while in $100 \% \mathrm{D}_{2} \mathrm{O}$ this was increased to $60 \%$ of the cells (Fig. 2B). After 24 hours, the cells grown in $0 \% \mathrm{D}_{2} \mathrm{O}$ had entered stationary phase (Fig. 1A) and were therefore not septated (Fig. 2AB). However, at $100 \% \mathrm{D}_{2} \mathrm{O}$ about $60 \%$ of the cells were still septated (Fig. 2B) and about 20\% displayed multiple septa (Fig. 2AB). In addition, an increased thickness of 
septa was visible already after 5 hours in $\mathrm{D}_{2} \mathrm{O}$, which was succeeded by unevenly shaped septa after 24 hours (Fig. 2A).

By transmission electron microscopy we confirmed that cells grown for 24 hours in $\mathrm{D}_{2} \mathrm{O}$ appeared swollen and displayed thickened cell walls (Fig. 2CD). Accordingly, cells incubated for 24 hours in $\mathrm{D}_{2} \mathrm{O}$-containing medium were resistant to the cell wall degrading enzyme $\beta$-glucanase, supporting that, unlike the situation for bacteria [19], $\mathrm{D}_{2} \mathrm{O}$ causes cell wall thickening of yeast cells (Fig. 2E). The S. pombe septum consists of primary (outer) and secondary (inner) septa that are made up of different glucans [30]. The secondary septum will eventually form the cell wall at the tip of the daughter cell. Both the primary septa (white layer) and secondary septa (grey layers flanking the primary septum) were thicker for cells grown for 24 hours in $\mathrm{D}_{2} \mathrm{O}$ (Fig. 2CD). In general, septum formation appeared abnormal in $\mathrm{D}_{2} \mathrm{O}$. For example, in some of the $\mathrm{D}_{2} \mathrm{O}$-treated cells we observed an asymmetrical septum growth from only one side (Fig. 2D, panels e, g, and k), while for the control cells, the septa always grew uniformly inwards (Fig. 2D, panels a-c). Once the septa formed, their closure appeared normal, but for the cells in $\mathrm{D}_{2} \mathrm{O}$, septum material continued to build up, leading to strongly thickened secondary septa (Fig. 2D, panels d-k). Since the primary septa were stabilized in $\mathrm{D}_{2} \mathrm{O}$, the cells failed to detach and remained associated with sister cells from previous generations (Fig. 2D, panel j). However, rather than reinitiating another cell cycle and forming a chain of cells, most of the multiseptated cells appeared to have formed the second or third septum near the original septum (Fig. 2D, panels e, f, and j), and not between nuclei, indicating that no further nuclear division occurred. This may suggest that $\mathrm{D}_{2} \mathrm{O}$ affects the septation initiation network [31]. Moreover, in some cells we observed that the second or third septum seemed to branch from the original septum, or to grow perpendicular to it (Fig. 2D, panels $i$ and j).

\section{$\mathrm{D}_{2} \mathrm{O}$ affects both the actin and tubulin cytoskeleton}


175 To determine if the cytoskeleton was affected, wild type cells carrying the LifeAct-GFP actin marker and GFP-tagged $\alpha$-tubulin (Atb2) were exposed to $\mathrm{D}_{2} \mathrm{O}$ and analyzed by fluorescence microscopy. In S. pombe the actin cytoskeleton typically appears as cortical patches located mainly at the growing cell tips during interphase and as a contractile ring, which forms during mitosis [32]. The tubulin cytoskeleton is composed of cables that extend between the cell ends in interphase and as a dense spindle between the sister chromatids during mitosis [32].

Upon treatment with $\mathrm{D}_{2} \mathrm{O}$, we observed that the actin patches were no longer concentrated at the cell tips, but rather appeared more evenly distributed throughout the cells (supporting information, Fig. S1A). The formation of the contractile ring, however, appeared normal (supporting information, Fig. $\mathrm{S} 1 \mathrm{~A})$. In response to $\mathrm{D}_{2} \mathrm{O}$, the tubulin cables were shorter, more numerous, and in some cells perpendicular rather than parallel to the cell (supporting information, Fig. S1B). However, similar to the situation with the actin cytoskeleton in mitosis, the mitotic spindle appeared unaffected by $\mathrm{D}_{2} \mathrm{O}$ (supporting information, Fig. S1B). Thus, unlike the situation in mammalian cells [16], the mitotic spindle was formed and appeared normal even after prolonged incubation in $\mathrm{D}_{2} \mathrm{O}$.

\section{$\mathrm{D}_{2} \mathrm{O}$ inhibits meiosis}

To test whether the solvent replacement affected cell cycle progression, cells exposed to different concentrations of $\mathrm{D}_{2} \mathrm{O}$ were analyzed for DNA content by DNA staining and automated microscopy. In S. pombe, cytokinesis normally occurs in $\mathrm{S}$ phase and cells in $\mathrm{G}_{1}$ and $\mathrm{S}$ phase are therefore binuclear and, by DNA staining, indistinguishable from the cells in $\mathrm{G}_{2}$. Accordingly, the DNA content profile presents as a single $2 \mathrm{~N}$ peak. After five hours of exponential growth in $\mathrm{D}_{2} \mathrm{O}$, the DNA peak remained unchanged. However, we note the appearance of a small population with 4N DNA content (supporting information, Fig. S2A), which may represent cells that have re-replicated DNA without prior mitosis or cells that have failed to undergo cytokinesis. After 24 hours, when the cultures with 
low concentrations of $\mathrm{D}_{2} \mathrm{O}$ had entered stationary phase with some cells arrested in the $\mathrm{G}_{1}$ phase, the $1 \mathrm{~N}$ peak was still not evident for cells grown at $75 \%$ or $100 \% \mathrm{D}_{2} \mathrm{O}$ (supporting information, Fig. $\mathrm{S} 2 \mathrm{~A})$. This may indicate a reduced progression through mitosis, whereas the sharp $2 \mathrm{~N}$ peak indicates that the cells spend a relatively short time period in S phase, suggesting that progression through $\mathrm{S}$ phase is not strongly affected. To more directly test whether mitosis was affected, the number of cells displaying spindles was determined using the Atb2-GFP strain. After 24 hours in $\mathrm{D}_{2} \mathrm{O}$, we observed a small increase in the number of cells with spindles (supporting information, Fig. S2B), indicating that $\mathrm{D}_{2} \mathrm{O}$ only causes a slightly slowed progression through mitosis, and the reduced cell growth of S. pombe cells in $\mathrm{D}_{2} \mathrm{O}$ is therefore most likely caused by an overall slowing of the cell cycle.

To test if meiosis was affected, a wild type strain $\left(h^{90}\right)$ was starved for nitrogen in the presence of $\mathrm{H}_{2} \mathrm{O}$ or $\mathrm{D}_{2} \mathrm{O}$. After two days, multiple asci were evident for the cells grown on the $\mathrm{H}_{2} \mathrm{O}$ control medium, whereas for cells incubated on $\mathrm{D}_{2} \mathrm{O}$ medium we were never able to detect any asci (supporting information Fig. S3). Accordingly, iodine stained the starch in spore walls dark for the cells on the $\mathrm{H}_{2} \mathrm{O}$ medium, but failed to stain the cells on the $\mathrm{D}_{2} \mathrm{O}$ medium (supporting information Fig. S3AC), suggesting that zygote formation and/or meiosis is severely inhibited by $\mathrm{D}_{2} \mathrm{O}$. Using diploid cells, we observed numerous asci when the cells were incubated in $\mathrm{H}_{2} \mathrm{O}$, but only a few asci for cells on $\mathrm{D}_{2} \mathrm{O}$ medium (supporting information Fig. S3BC). Collectively, these data indicate that $\mathrm{D}_{2} \mathrm{O}$ inhibits mating and meiosis. An obvious hypothesis is that the mating defect, at least in part, is caused by the $\mathrm{D}_{2} \mathrm{O}$-induced cell wall thickening.

\section{$\mathrm{D}_{2} \mathrm{O}$ blocks glucose metabolism through inhibition of glucose-6-phosphate isomerase}

Since the isotope effects of $\mathrm{D}_{2} \mathrm{O}$ are likely to disturb metabolism [33], we decided to investigate whether $\mathrm{D}_{2} \mathrm{O}$ affects the kinetics of enzymes in the glycolytic pathway on a short timescale. This was accomplished using hyperpolarized NMR (signal enhanced nuclear magnetic resonance) [34] which 
223 allows detailed metabolic mapping of glycolysis. A ${ }^{13} \mathrm{C}$-labelled glucose tracer was fed to live cells in either $100 \% \mathrm{D}_{2} \mathrm{O}$ or $100 \% \mathrm{H}_{2} \mathrm{O}$ MES buffer for 2 or 10 minutes, after which the metabolism was quenched in acid and the soluble metabolites extracted. This extract was then hyperpolarized and analyzed with single spectrum ${ }^{13} \mathrm{C}$-NMR. Examples of an NMR spectra from cells fed with the glucose tracer in $\mathrm{D}_{2} \mathrm{O}$ and $\mathrm{H}_{2} \mathrm{O}$, respectively, are shown in Fig. 3A. The crowded spectral region from 60-100 ppm contains signals from the substrate glucose. The singlet signal at $24 \mathrm{ppm}$ originates from an added standard, which allows quantification and direct comparison between the metabolite signals in the different spectra [35]. This comparison clearly revealed that several metabolic changes appear when $S$. pombe is fed glucose in $\mathrm{D}_{2} \mathrm{O}$. In particular, we noted the accumulation of a large pool of $\alpha$ glucose-6-phosphate ( $\alpha$-G6P) (Fig. 3A, blue insert), suggesting that the $\alpha$ anomer is being metabolised more slowly in $\mathrm{D}_{2} \mathrm{O}$. Whereas $\beta$-G6P is readily used as a substrate in the pentose phosphate pathway (PPP), $\alpha$-G6P must be converted to $\beta$-G6P for use in PPP or to $\beta$-fructose-6phosphate ( $\beta$-F6P) for use in glycolysis. A single enzyme, glucose-6-phosphate isomerase (GPI, EC 5.3.1.9), is responsible for both types of isomerase activities (https://www.genome.jp/kegg/). The PPP was indeed active, as demonstrated by the signals from 6-phosphogluconate (6PGA) (Fig. 3A, red insert). The 6PGA pool was approximately twice as large in $\mathrm{D}_{2} \mathrm{O}$ as in $\mathrm{H}_{2} \mathrm{O}$. That the activity of PGI could be negatively affected by the exchange of $\mathrm{H}_{2} \mathrm{O}$ for $\mathrm{D}_{2} \mathrm{O}$ is plausible since the mechanism of catalytic isomerization involves several proton transfer steps [36].

The doublet signal at about $179.4 \mathrm{ppm}$, assigned to gluconate (GA) (Fig. 3A), confirms that the gluconate shunt is active in $S$. pombe cells $[37,38]$. In 30 -sec. time-resolved data (supporting information, Fig. S4) only gluconate could be detected and the gluconate shunt seemed to be unaffected by $\mathrm{D}_{2} \mathrm{O}$.

The accumulation of $\alpha$-G6P in the $\mathrm{D}_{2} \mathrm{O}$-exposed cells is already apparent after 2 minutes of incubation with the glucose tracer (supporting information, Fig. S5). However, in order to facilitate 
quantification and comparison of the amount of G6P under the two studied conditions, exposure times of 10 minutes were used, revealing an about 8 times larger pool of G6P in $\mathrm{D}_{2} \mathrm{O}$ exposed cells (Fig. 3B). In summary, glycolysis as well as the pathway leading to PPP are affected negatively by an inhibition of $\alpha$-G6P isomerization in $S$. pombe cells exposed to $\mathrm{D}_{2} \mathrm{O}$ (Fig. 3C). We conclude that, under these conditions, S. pombe cells use a highly active gluconate shunt to produce PPP metabolites from glucose, which allow the cells to bypass GPI.

\section{$\mathrm{D}_{2} \mathrm{O}$ induces a cellular stress response}

Recently, it was reported that deuterium causes dramatic changes in the E. coli proteome [19]. To determine if the $\mathrm{D}_{2} \mathrm{O}$-triggered growth inhibition was accompanied by differential gene expression, total RNA was purified from S. pombe cells under each condition in quadruplicates, and analyzed by next-generation sequencing. The four repeats of each condition clustered in separate groups (Fig. 4AB). In total, we could assign read counts to 6992 of 7015 annotated genes in the S. pombe genome. By setting a significance cut-off of absolute $\log 2$ fold change $\geq 2$ between the groups and adjusted $p$ values $\leq 5 \%$ (false discovery rate, FDR), we identified 178 genes that were significantly upregulated, while 38 genes were significantly down-regulated after five hours with $\mathrm{D}_{2} \mathrm{O}$. After 24 hours in $\mathrm{D}_{2} \mathrm{O} 284$ genes were significantly up-regulated and 51 genes were significantly downregulated. The identified differentially expressed genes are listed in the supporting material (supporting material file 1). The sequencing data has been uploaded to Gene Expression Omnibus (https://www.ncbi.nlm.nih.gov/geo/; accession no. GSE119785). To further test the quality of the dataset, we quantified the mRNA by real-time PCR of selected up-regulated genes. In agreement Fig. S6). 
When analyzing the differentially expressed genes, we noted a strong $\mathrm{D}_{2} \mathrm{O}$-dependent downregulation of several cytosolic and mitochondrial tRNAs (Table S1). This is in line with earlier observations in E. coli [39] and the reduced abundance of translational proteins recently observed by proteomics [19]. Comparison of our datasets with previous transcriptomic analyses in fission yeast (Chen et al., 2003; Poulsen et al., 2017; Vjestica et al., 2013) indicated that $\mathrm{D}_{2} \mathrm{O}$ causes a general stress response in the cells. Thus, the $\mathrm{D}_{2} \mathrm{O}$-triggered gene expression pattern resembled those observed upon heat shock, deletion of the Hsf1 transcriptional repressor Mas5 or the Hsp70 chaperone Ssa2, or overexpression (OE) of the co-chaperone Bag101 (Fig. 4CD). We therefore tested if prior activation of the stress response pathway conferred any fitness advantage to the cells in the presence of $\mathrm{D}_{2} \mathrm{O}$. To this end, wild type cells were given a 30 minute heat shock at $43{ }^{\circ} \mathrm{C}$ immediately prior to testing growth in the presence of $\mathrm{D}_{2} \mathrm{O}$ on solid media. However, rather than protecting the cells from $\mathrm{D}_{2} \mathrm{O}$, this revealed a slight, but reproducible, decreased $\mathrm{D}_{2} \mathrm{O}$ tolerance (Fig. $4 \mathrm{E})$, suggesting that induction of molecular chaperones, oxidoreductases and other stress-relieving proteins are unable to counteract the adverse effects of $\mathrm{D}_{2} \mathrm{O}$. Similarly, applying oxidative stress via a pre-treatment of cells for 1 hour with $0.7 \mathrm{mM} \mathrm{H}_{2} \mathrm{O}_{2}$ also did not provide protection from $\mathrm{D}_{2} \mathrm{O}$ (Fig. 4F). Conversely, pre-incubating cells for 5 hours with $100 \% \mathrm{D}_{2} \mathrm{O}$ led to an increased survival of cells after a severe heat shock (Fig. 4G) and an increased growth in the presence of $\mathrm{H}_{2} \mathrm{O}_{2}($ Fig. $4 \mathrm{H})$. This suggests that the $\mathrm{D}_{2} \mathrm{O}$-triggered induction of the stress-response genes leads to increased tolerance towards heat-shock and oxidative stress conditions.

Screening the S. pombe gene deletion library for $\mathrm{D}_{2} \mathrm{O}$ sensitive or $\mathrm{D}_{2} \mathrm{O}$ resistant mutants

Previous studies in budding yeast have shown that heavy water sensitivity is a conditional phenotype and that a loss-of-function mutant in ASP5, encoding an aspartate aminotransferase, is hypersensitive to $\mathrm{D}_{2} \mathrm{O}[20]$. As a next step, we therefore explored the genetic requirements for $\mathrm{D}_{2} \mathrm{O}$ tolerance by 
individually screening 3233 different mutants from the fission yeast haploid gene deletion collection for hypersensitivity to $\mathrm{D}_{2} \mathrm{O}$ on solid media.

Stationary phase cells were replica plated in 384-pin format onto YES plates with $0 \%$ or $100 \% \mathrm{D}_{2} \mathrm{O}$.

This concentration of $\mathrm{D}_{2} \mathrm{O}$ was used because it completely blocked growth of a deletion strain in the ASP5 orthologue in fission yeast, caa1, but also impaired the growth of wild type cells (Fig. 5A), so both $\mathrm{D}_{2} \mathrm{O}$ hypersensitive and resistant mutants could be scored. We selected mutants with reduced growth on $\mathrm{D}_{2} \mathrm{O}$ medium, but excluded mutants with slow growth on $0 \% \mathrm{D}_{2} \mathrm{O}$ medium. This led to 39 appeared resistant to $\mathrm{D}_{2} \mathrm{O}$.

To assess the validity of the screen, we tested selected $\mathrm{D}_{2} \mathrm{O}$ sensitive mutants and the pmk1 $\Delta$ strain in growth assays on solid media. This revealed that the pmk1 $\Delta$ strain was slightly resistant to $\mathrm{D}_{2} \mathrm{O}$, while the selected sensitive mutants all displayed a reduced $\mathrm{D}_{2} \mathrm{O}$ tolerance (Fig. 5B). In addition, using the BioGRID database (https://thebiogrid.org/) [40] we noted several previously identified genetic interactions between many of the $\mathrm{D}_{2} \mathrm{O}$ hypersensitive/resistant strains, including ones between the $\mathrm{D}_{2} \mathrm{O}$ tolerant pmk1 $\Delta$ strain and the $\mathrm{D}_{2} \mathrm{O}$ sensitive $c c h 1 \Delta[41,42], \operatorname{rga} 7 \Delta[43,44], \operatorname{cph} 2 \Delta$ [45] and swd2 $\Delta$ [45] (Fig. 5C).

\section{$\mathrm{D}_{2} \mathrm{O}$ activates the cell wall integrity pathway}

To obtain further insight into the biological effects of the solvent replacement, we set up a screen for spontaneous $\mathrm{D}_{2} \mathrm{O}$ resistant mutants. Wild type cells were inoculated in $100 \% \mathrm{D}_{2} \mathrm{O}$ rich medium in 20 separate tubes and incubated at $30^{\circ} \mathrm{C}$. After about one week, slight growth was apparent in four of the tubes, suggesting that independent spontaneous mutations that allowed for $\mathrm{D}_{2} \mathrm{O}$ tolerance had occurred in these cultures. To avoid selecting clones, cells from each culture were spread on 100\% 
$\mathrm{D}_{2} \mathrm{O}$ plates and only one well-isolated large colony from each plate was selected. This led to the isolation of three independent heavy water resistant (hwr) mutants (hwr1-3), that all displayed a markedly increased growth in the presence of $\mathrm{D}_{2} \mathrm{O}$, but otherwise appeared normal (Fig. 6A). The increased tolerance to $\mathrm{D}_{2} \mathrm{O}$ was also evident on $100 \% \mathrm{D}_{2} \mathrm{O}$ minimal media (supporting information, Fig. S7). However, the hwr mutants were not resistant to the slight growth inhibitory effect conferred by deuterated glucose on minimal medium (supporting information, Fig. S7), indicating that the isolated $h w r$ mutants were specifically tolerant to the solvent replacement effect.

Since the isolated hwr strains were the result of spontaneous mutations, as opposed to mutagenesis induced by chemicals or irradiation, we reasoned that their genome sequences were likely highly similar with the exception of the mutations causing $\mathrm{D}_{2} \mathrm{O}$ resistance. We therefore analyzed the $h w r$ strains and their wild type parent by whole genome sequencing using Illumina HiSeq2000 highthroughput sequencing technology. The average sequence coverage was greater than $1000 \mathrm{reads} / \mathrm{bp}$ for all samples. The full sequencing datasets are deposited at the Sequence Read Archive (https://www.ncbi.nlm.nih.gov/sra; accession no. SRP161455). Comparison of obtained sequences from the hwr strains and the wild type control revealed a match, except for the listed changes (Table 2, and supporting material file 2).

When studying the mutated genes in the hwr1-3 strains (Table 2), we noticed that several have been linked to tRNA metabolism (gta2 and trm72) and cell wall formation (pck2, mkh1 and pek1). The kinases Pck2, Mkh1 and Pek1 were mutated in the hwr3, hwr2 and hwr1 strains, respectively. These kinases function as upstream activators of Pmk1 in the so-called cell integrity pathway [46, 47], which is activated by cell wall damage to upregulate synthesis of various cell wall components [48], while the Rho2 GAP, Rga7, restricts signaling through this pathway (Fig. 6B) [43, 44]. None of these genes are essential, but except for the $\mathrm{D}_{2} \mathrm{O}$-sensitive $r g a 7 \Delta$ and $\mathrm{D}_{2} \mathrm{O}$-tolerant pmk1 1 , the deletion mutants were not included in the screened knock-out library. The pek1 and mkh1 mutations both result in 
342 frame shifts in regions encoding the respective kinase domains of Pek1 and Mkh1 that we predict will 343 cause loss of function, while $p c k 2$ contained a missense mutation (supporting information, Table S2). 344 These changes were confirmed by PCR and Sanger sequencing (supporting information, Fig. S8$345 \mathrm{~S} 10)$. We therefore continued to test if the $\mathrm{D}_{2} \mathrm{O}$ tolerant phenotype was also evident in the independent $346 p c k 2-8, m k h 1 \Delta$, and pek1 $\Delta$ strains. Indeed, in growth assays, these strains appeared more resistant to $347 \mathrm{D}_{2} \mathrm{O}$ than wild type cells (Fig. 6C), thus phenocopying the hwr strains. In agreement with this, the 348 cell septation problems observed for wild type cells in $\mathrm{D}_{2} \mathrm{O}$ were reduced in the $h w r$ strains (Fig. 6D). 349 The conclusions above suggest that $\mathrm{D}_{2} \mathrm{O}$ activates the cell integrity pathway and blocking this 350 pathway leads to an increased fitness at high concentrations of $\mathrm{D}_{2} \mathrm{O}$, presumably by limiting synthesis 351 of glycans and/or other cell wall components. To test this prediction, we directly analyzed the 352 activation of the cell integrity pathway in response to $\mathrm{D}_{2} \mathrm{O}$ in a wild type strain, expressing HA-tagged 353 Pmk1. This revealed a marked increase in the level of phosphorylated Pmk1 after 5 and 24 hours in $354 \mathrm{D}_{2} \mathrm{O}$-containing media (Fig. 6E), which further suggests that the solvent replacement activates the 355 cell integrity pathway. In turn, blocking the Pck2-Mkh1-Pek1-Pmk1 signaling axis, at least partially, 356 alleviates the $\mathrm{D}_{2} \mathrm{O}$-triggered cell wall and growth defects, while activating it by deletion of rga7 357 increases $\mathrm{D}_{2} \mathrm{O}$ sensitivity (Fig. 6B). 


\section{Discussion}

In the present study, we have systematically addressed the cellular and biochemical consequences of exchanging $\mathrm{H}_{2} \mathrm{O}$ for $\mathrm{D}_{2} \mathrm{O}$ in eukaryotic cells using $S$. pombe as a model organism. The effect of $\mathrm{D}_{2} \mathrm{O}$ cannot directly be compared to any other insults that a cell can experience because it entails an almost complete substitution of solvent. This possibility of solvent change for biological reactions and life as such is unique. In some ways it can be compared to changing $\mathrm{pH}$, which also implies global solvent effects, but contrary to shifts in $\mathrm{pH}$, which are common in nature and has well-defined biological responses, a shift to $\mathrm{D}_{2} \mathrm{O}$ is completely abiotic and something that we can say with absolute certainty that cellular responses have not experienced before. Thus, querying the effects of $\mathrm{D}_{2} \mathrm{O}$ on cellular growth and metabolism highlights subtleties of the biophysical properties of $\mathrm{H}_{2} \mathrm{O}$ as solvent for biological processes. A priori one would expect that the toxic effects of replacing $\mathrm{H}_{2} \mathrm{O}$ with $\mathrm{D}_{2} \mathrm{O}$ would be the sum of multiple smaller pleiotropic effects, and it is therefore surprising that this work demonstrates that modification of a single signaling pathway is sufficient to overcome the growth defect induced by the solvent replacement.

In agreement with early studies using human cells and other model systems [5], we observed that high concentrations of $\mathrm{D}_{2} \mathrm{O}$ strongly reduced cell growth. In principle, this effect can be the result of deuteration of various biomolecules or the solvent exchange effect. When $\mathrm{D}$ is incorporated into biomolecules, this can occur either de novo, where $\mathrm{D}_{2} \mathrm{O}$ donates $\mathrm{D}$ atoms during de novo biosynthesis, or by exchange of loosely bound hydrogens in preexisting biomolecules. Hydrogen covalently bound to carbon does not exchange, and generation of C-D bonds therefore requires de novo synthesis. Since we only observed minor effects of exchanging glucose with deuterated glucose on minimal medium, metabolic incorporation of D into C-D bonds does not appear to strongly affect the growth of $S$. pombe. The resulting changes in stability and/or dynamics of proteins and other biomolecules, carrying C-D bonds, therefore appears negligible next to the observed solvent effects of exchanging 
$\mathrm{H}_{2} \mathrm{O}$ for $\mathrm{D}_{2} \mathrm{O}$. However, upon substituting $\mathrm{H}_{2} \mathrm{O}$ with $\mathrm{D}_{2} \mathrm{O}$, loosely-bound hydrogen atoms such as those bound to amide/amino nitrogen or hydroxy oxygen will, depending on solvent exposure, exchange with deuterium atoms in the $\mathrm{D}_{2} \mathrm{O}$ solvent. Here, the properties of hydrogen bonds compared to the stronger and slightly longer deuterium bonds likely become highly relevant. Hence, deuteron transfer reactions are expected to be less efficient than the corresponding proton transfer reactions. Also, the more ordered nature of $\mathrm{D}_{2} \mathrm{O}$ compared to $\mathrm{H}_{2} \mathrm{O}$ suggests that proteins and other biomolecules are less dynamic and more tightly wrapped in $\mathrm{D}_{2} \mathrm{O}$ than in $\mathrm{H}_{2} \mathrm{O}$ [49]. Accordingly, $\mathrm{D}_{2} \mathrm{O}$ is known to both directly (as a solvent) and indirectly (through deuteration) affect the structure and stability of proteins and other macromolecules in vitro [25, 50-54].

One of the direct effects of the solvent exchange that we observed was on the central metabolism, where we directly and on a very short time-scale ( 2 minutes) noted a clear accumulation of $\alpha$-G6P, suggesting that G6P isomerase is inhibited. The solvent exchange also led to an activation of a general stress response pathway. Typically, this pathway is provoked by protein misfolding events, suggesting that solvent exchange may destabilize proteins in vivo. However, inducing molecular chaperones through a heat shock prior to incubation with $\mathrm{D}_{2} \mathrm{O}$ did not protect cells from the $\mathrm{D}_{2} \mathrm{O}$ induced growth retardation. This indicates that activation of the stress response pathway is not tuned to counter the adverse effects of the solvent exchange, although it has been reported that overexpression of Hsp70 may protect budding yeast cells from $\mathrm{D}_{2} \mathrm{O}$ [55]. In line with chaperones being unable to protect fission yeast cells against $\mathrm{D}_{2} \mathrm{O}$, we were unable to adapt $S$. pombe to growth at higher $\mathrm{D}_{2} \mathrm{O}$ concentrations and we did not identify any chaperone mutants as hypersensitive or resistant to $\mathrm{D}_{2} \mathrm{O}$. Conversely, it was not surprising to find that pre-treating cells with $\mathrm{D}_{2} \mathrm{O}$ led to an increased tolerance towards heat and oxidizing conditions, which is most likely caused by the $\mathrm{D}_{2} \mathrm{O}$ induced activation of the stress response pathway. The activated stress response and slow growth phenotypes are probably also connected with our observation that exposure to $\mathrm{D}_{2} \mathrm{O}$ caused a strong 
decrease in the expression of several tRNAs. In budding yeast and in bacteria it has been shown that tRNAs are degraded in response to stress conditions [56,57], and we speculate that perhaps a similar mechanism operates in S. pombe.

The multiple effects, we observed for cells in the presence of $\mathrm{D}_{2} \mathrm{O}$, not surprisingly, suggest that the effects of the solvent exchange are pleiotropic. Accordingly, it is easy to imagine a number of genetic defects that may cause cells to become hypersensitive to $\mathrm{D}_{2} \mathrm{O}$. However, it is harder to reconcile $\mathrm{D}_{2} \mathrm{O}$ resistant mutants with the observed pleiotropic phenotypes, and although heavy metals, oxidizing agents and increased temperatures also induce multiple cellular effects [58-61], these conditions occur naturally and cells have therefore evolved specific transcriptional programs driving the expression of proteins that fend against such insults. Since the natural abundance of $\mathrm{D}_{2} \mathrm{O}$ is miniscule $\left(<0.02 \%\right.$ in water), any $\mathrm{D}_{2} \mathrm{O}$ resistant mutant must therefore be a consequence of some cellular pathway, which indirectly improves fitness in response to $\mathrm{D}_{2} \mathrm{O}$. We identified a null mutant in pmk1 (orthologue of human MAPK7) which displays increased tolerance to $\mathrm{D}_{2} \mathrm{O}$. This is in line with Pmk1 acting as a MAP kinase that regulates cell wall biogenesis $[44,62,63]$ and the observed $\mathrm{D}_{2} \mathrm{O}$-induced cell wall and cell septation defects. Accordingly, the cell integrity pathway is activated in response to $\mathrm{D}_{2} \mathrm{O}$, and when we selected for spontaneous $\mathrm{D}_{2} \mathrm{O}$-tolerant strains, we recovered mutants in other components of the pathway. Moreover, we found that deletion of the Rho2 GAP, Rga7, which normally down-regulates the cell integrity pathway [43, 44], leads to a $\mathrm{D}_{2} \mathrm{O}$ hypersensitive phenotype. However, besides $\operatorname{rga} 7 \Delta$, other mutants that we scored as $\mathrm{D}_{2} \mathrm{O}$ sensitive have also been reported in BioGRID to display genetic interactions with components of the cell integrity pathway (supporting material file 3). Intriguingly, the $\mathrm{D}_{2} \mathrm{O}$-dependent cell wall effects, we report here, resemble those observed upon deletion of the kinase Kin1, which regulates cell polarity $[64,65]$. Similar to $\mathrm{D}_{2} \mathrm{O}$ treated cells, the $\operatorname{kin} 1 \Delta$ strain displays positive genetic interactions with

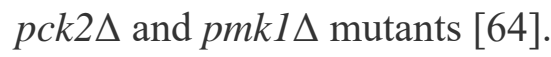


431 Activation of the cell integrity pathway is in agreement with its role in mediating an appropriate response to allow survival during sudden changes in water activity [66] and earlier studies suggesting that $\mathrm{D}_{2} \mathrm{O}$ causes osmotic stress $[67,68]$. It does, however, pose the question of how the solvent exchange, or what property of $\mathrm{D}_{2} \mathrm{O}$, causes activation of the pathway? Several upstream membranespanning sensors of the cell integrity pathway, including Wsc1 and Mid2, have been identified in Saccharomyces cerevisiae. Recent studies suggest that these sensors physically couple the cell wall with the plasma membrane, and in a spring-like manner function to sense mechanical perturbations or elasticity changes in the cell wall and/or plasma membrane [69]. Accordingly, $\mathrm{D}_{2} \mathrm{O}$ is known to affect phospholipid membranes [70] and ion channels [68], and we speculate that this or related effects on the cell wall glycans may cause a direct activation of the cell integrity pathway.

Identifying $\mathrm{D}_{2} \mathrm{O}$-resistant strains has important practical applications, since the phenotypes imposed by $\mathrm{D}_{2} \mathrm{O}$ severely hinder the production of deuterated proteins for structural studies [71], but also potentially for biological production of deuterated pharmaceuticals, which in some cases are superior to their protonated counterparts [72], and are therefore increasingly being considered as drug candidates [73-75]. Although bacteria can be adapted to grow in $100 \% \mathrm{D}_{2} \mathrm{O}$ [17], growth is often poor and the bacteria quickly lose the $\mathrm{D}_{2} \mathrm{O}$ tolerance when returned to $\mathrm{H}_{2} \mathrm{O}$ media. The results presented here provide an important first step towards an understanding of how $\mathrm{D}_{2} \mathrm{O}$ affects cell biology and for generating $\mathrm{D}_{2} \mathrm{O}$ tolerant strains for production of deuterated biomolecules. 


\section{Materials and Methods}

\section{Heavy water and deuterated glucose}

The used $\mathrm{D}_{2} \mathrm{O}$ (deuterium oxide) was purchased as $99.8 \% \mathrm{D}_{2} \mathrm{O} / 0.2 \% \mathrm{H}_{2} \mathrm{O}$ (Sigma). Deuterated glucose (D-glucose-1,2,3,4,5,6,6-d7) was purchased as 97 atom \% D (Sigma).

\section{Yeast strains and techniques}

The fission yeast strains that were used in this study are all derivatives of the wild type $972 h^{-}$and $975 h^{+}$heterothallic strains that either carry no auxotrophic markers (no marker wild type), or the three auxotrophic markers ura4-D18, leu1-32, and ade6-216 (3 marker wild type). The gene deletion strains were from the fission yeast haploid deletion library purchased from Bioneer [76]. The LifeActGFP and atb2-GFP strains have been described before [77, 78]. The pck2-8 strain was kindly provided by Dr. Jeremy Hyams. The pmk1-HA strain was kindly provided by Dr. Marisa Madrid [47]. Growth assays in liquid YES (yeast extract with supplements) media (5 g/L yeast extract, $30 \mathrm{~g} / \mathrm{L}$ glucose, $225 \mathrm{mg} / \mathrm{L}$ adenine, $225 \mathrm{mg} / \mathrm{L}$ uracil, $225 \mathrm{mg} / \mathrm{L}$ leucine) were performed at $30{ }^{\circ} \mathrm{C}$ with vigorous shaking by following the optical density (OD) at $600 \mathrm{~nm}$. Growth assays on solid media, either YES media (YES medium with $20 \mathrm{~g} / \mathrm{L}$ agar) or EMM2 (Edinburgh minimal media) [79, 79] were performed at 25 or $30^{\circ} \mathrm{C}$ essentially as described [80]. Sporulation assays were performed using malt extract agar plates (30 g/L malt extract, $20 \mathrm{~g} / \mathrm{L}$ agar). For iodine staining, solid iodine was heated in a closed beaker and the plates briefly exposed to the iodine vapor. The wild type diploid strain was constructed by mating ade6-210 $h^{+}$cells with ade6-216 $h^{-}$cells on malt extract and selecting for cells that could grow in the absence of adenine.

$\beta$-glucanase (Sigma) resistance was determined (in water) for cells grown for 25 hours in $100 \% \mathrm{D}_{2} \mathrm{O}$ based YES medium as described [81]. 
473 Cell viability was determined by staining cells using VitaBright-48 (ChemoMetec) and a

474 NucleoCounter NC-3000 (ChemoMetec) as described by the manufacturer.

475 To monitor cell cycle progression, cultures treated or untreated with $\mathrm{D}_{2} \mathrm{O}$, were stained with SYTOX 476 Green and the cellular DNA content was quantified using a NucleoCounter NC-3000 (ChemoMetec) 477 as described by the manufacturer.

\section{Cell imaging and microscopy}

480 Calcofluor white (Sigma) staining was used to monitor cell septation as described previously [82]. 481 Hoechst (Sigma) staining was used to mark the nucleus. Cells were observed on $2 \%$ agarose pads 482 made in EMM with $\mathrm{H}_{2} \mathrm{O}$ or $\mathrm{D}_{2} \mathrm{O}$. Samples were examined using a Zeiss $\mathrm{Z} 1$ AxioObserver inverted 483 fluorescence microscope, equipped with a motorized stage, in a temperature-controlled incubation chamber. A 100x, 1.4 NA oil immersion lens and a Cool-Snap HQ2 CCD camera (Photometrics) controlled by Axiovision software (Zeiss) was used for image capture. All image analysis was performed using ImageJ [83]. Electron microscopy was performed essentially as described [84].

A previously published protocol [35] was followed for substrate incubation, metabolite extraction, and extract hyperpolarization. Briefly, $100 \mu \mathrm{L} 120 \mathrm{mM} \mathrm{U-}{ }^{13} \mathrm{C}, \mathrm{d}_{7}$ glucose dissolved in either $\mathrm{D}_{2} \mathrm{O}$ - or $\mathrm{H}_{2} \mathrm{O}$-based morpholinoethanesulfonate (MES) buffer (50 mM MES, $100 \mathrm{mM} \mathrm{NaCl}, \mathrm{pH}$ 5.5) was added to the yeast cells and the respective samples were incubated for 2 minutes or 10 minutes at 30 ${ }^{\circ} \mathrm{C}$ after which the metabolism was stopped by addition of $400 \mu \mathrm{L}$ perchloric acid and the soluble metabolites were extracted according to the protocol. The freeze-dried extracts were re-dissolved in a hyperpolarization matrix and polarized at $3.35 \mathrm{~T}$ and $1.4^{\circ} \mathrm{K}$. Hyperpolarized extracts were hereafter dissolved in $4 \mathrm{~mL} \mathrm{D}_{2} \mathrm{O}$ or $\mathrm{H}_{2} \mathrm{O}$ based MES-buffer $\mathrm{pH} 5.5$ and injected into a $5 \mathrm{~mm}$ NMR tube and a 
single spectrum ${ }^{13} \mathrm{C}-\mathrm{NMR}$ was acquired on a $9.4 \mathrm{~T}$ Varian Inova spectrometer immediately with a 90 degree pulse.

NMR spectra were analyzed with the MNova software. Metabolites were identified by reference to the human metabolome database [85].

\section{RNA sequencing}

Total RNA was isolated using the hot phenol method [86] from cells that were either untreated or treated with $100 \% \mathrm{D}_{2} \mathrm{O}$ for 5 or 24 hours. Conversion to cDNA and sequencing was performed by the Beijing Genome Institute using the Illumina sequencing as single-end with final read lengths of 50 bp after demultiplexing. This produced 23.9-24.1 million reads per sample. The raw reads were aligned to the $S$. pombe genome using bwa mem (v0.7.12) with default settings giving an alignment rate of 98.4-98.7\% for all 12 samples. Mapped reads were assigned to genes using GFOLD ('gfold count') followed by GFOLD statistical analysis ('gfold diff') to detect differentially expressed (DE) genes [87].

The significance cut-off for DE genes was set at FDR $\leq 5 \%$ and absolute log2 fold change $\geq 2$. For figures the DESeq2 (R package) [88] normalized gene counts ('rld') were used. The S. pombe reference genome and gene annotation were downloaded from GenBank (date stamped 27-FEB2015, Rel. 123, Last updated, Version 14). Supplementary data tables from Chen et al. (Chen et al., 2003) were downloaded from http://128.40.79.33/projects/stress/. The data from Vjestica et al. are primarily from the supplementary material (Vjestica et al., 2013).

Our annotation also includes rRNA, tRNA, ncRNA, snoRNA, and mitochondrial genes, that in many cases are not present in the older annotations used by Chen et al. (Chen et al., 2003) and Vjestica et al. (Vjestica et al., 2013). Thus, it was not possible to compare the expression levels of many, in 
particular non-coding, genes across the studies. The DESeq2 Bioconductor package in R (Anders et al., 2015) was used for statistical analyses of differentially expressed genes.

The S. pombe haploid gene deletion library was first pinned to YES $\left(0 \% \mathrm{D}_{2} \mathrm{O}\right)$ agar plates in 384 format. Once large colonies had formed, cells were transferred to YES with $0 \% \mathrm{D}_{2} \mathrm{O}$ and YES with $100 \% \mathrm{D}_{2} \mathrm{O}$ agar plates in 384 format. After 8 days of incubation at $30{ }^{\circ} \mathrm{C}$, the plates were photographed and cell growth was scored by manual inspection. All cell handling was performed using a ROTOR HDA pinning robot (Singer Instruments).

Screening for spontaneous $\mathrm{D}_{2} \mathrm{O}$-tolerant mutants and whole-genome sequencing

Wild type cells were inoculated in $1 \mathrm{~mL} 100 \% \mathrm{D}_{2} \mathrm{O}$ YES medium in separate tubes and incubated at $30{ }^{\circ} \mathrm{C}$. After about 1 week, when slight growth was apparent in some of the tubes, cells from each culture were spread on solid $100 \% \mathrm{D}_{2} \mathrm{O}$ YES media plates and only one single large colony from each plate was selected for further analyses. Genomic DNA was purified by phenol-chloroform extraction as described [89]. The purified DNA from the three selected hwr mutants and the wild type parent was sequenced by the Beijing Genome Institute. demultiplexing and produced 78.4-87.5 million read pairs per sample, which leads to an average coverage $>1000$ reads per reference base.

540 The raw reads were trimmed using Trimmomatic (v0.32; default setting except: HEADCROP=10, 541 SLIDINGWINDOW=4:30, MINLEN=30) [90]. The trimmed reads were aligned to the $S$. pombe genome (version ASM294v2.38) with 'bwa mem' (v0.7.15; default settings except: -M) [91] and the resulting alignments locally refined using Stampy (v1.0.32; default settings except: --sensitive-- 
544 bamkeepgoodreads -M) [92] for higher mapping sensitivity. With Picard tools (v4.0.1.1) 545 (http://broadinstitute.github.io/picard) the alignments were coordinate sorted (sortSam) and read 546 duplicates annotated (MarkDuplicates). The alignment rate was $>99 \%$ for all four samples.

547 To call variations (SNPs, insertions and deletions) between wild type cells and the three independent 548 hwr mutants we used GATK LeftAlignIndels followed by GATK Mutect2 (v4.0.1.1; default settings 549 except: -ploidy 1 -tumor $<$ Mutant $>$-normal $<$ Wild-type $>$ ) $[93,94]$. The Mutect2 generated list of 550 putative mutations were quality filtered with 'bcftools filter' (v1.3.1; settings: 'AF[0]>0.75'). 551 Mutations were also called on the alignment files using Freebayes (v1.2.0; default settings except: -552 ploidy 1 --min-alternate-count 5 --min-alternate-fraction 0.4 ) followed by quality filtering by 'bcftools 553 filter' (settings: 'AO>200 \&\& ODDS $>100 \& \&$ GL[*]<-100 \& \& AC=1') [95]. Mutect2 and Freebayes 554 agree on the main findings. The mutations were annotated to genes (ENSEMBL, S. pombe version ASM294v2.38) using ANNOVAR (version: July 17 2017) [96]. Comparison to the reference genome revealed that our strains contained two mutations on chromosome II (A153954T and T153964A) in the mal1 gene encoding maltase alpha-glucosidase resulting in a variant of Mal1 containing an R131R silent and F135I missense substitution.

559 Three mutations were selected for PCR validation, and multiple alignments in ClustalW comparing 560 the annotated full length gene, the wild type PCR sequences and the hwr PCR sequences all verified 561 the predicted mutations.

562 PCR sequencing was performed by Eurofins. The used primers were: $m k h 1$ forward: 563 GATAATGTGTATGACAATGACGC, mkh1 reverse: GCATGTCGTAAAGATTCGTG, pek1 564 forward: TGACGTCAAAAGGTCAAGTG, pek1 reverse: CTAATCAGACCAGACTTGACG, pck2 565 forward: AAGCCCAGATGGTCATG, pck2 reverse: GGATGAGTCATGACATCTTCTG. 
568 Whole cell lysates were prepared with TCA and glass beads as described [84]. Proteins were resolved 569 by SDS-PAGE on $12 \%$ acrylamide gels and subsequently transferred to nitrocellulose membranes 570 (0.2- $\mu \mathrm{m}$ pore size, Advantec, Toyo Roshi Kaisha Ltd.). The blots were blocked in PBS (133 mM $571 \mathrm{NaCl}, 2.7 \mathrm{mM} \mathrm{KCl}, 6.5 \mathrm{mM} \mathrm{Na}_{2} \mathrm{HPO}_{4}$, and $\left.1.5 \mathrm{mM} \mathrm{KH}_{2} \mathrm{PO}_{4}(\mathrm{pH} 7.4)\right)$ with $5 \%$ fat-free milk powder 572 and $0.01 \%$ Tween 20 . The antisera, diluted 1:1000, were as follows: anti-HA (clone 3F10, Roche), 573 anti-P-p44/42 (Phospho-p44/42 MAPK \#9101, Cell Signaling Technology), and anti- $\alpha$-tubulin (clone 574 TAT1, Abcam). Secondary HRP-conjugated antibodies were from Dako Cytomation. Blots were 575 developed using the Pierce ECL Plus detection kit (Thermo Scientific). 


\section{Acknowledgements}

The authors thank Dr. Marisa Madrid and Dr. Jeremy Hyams for sharing yeast strains, Dr. Shiraz Shah for help with the RNA sequencing and Dr. Genevieve Thon for help with screening the deletion library. In addition, we thank Mrs. Anne-Marie Lauridsen for expert technical assistance, and Dr. Kresten Lindorff-Larsen, Dr. Olaf Nielsen, Dr. Erik Boye, Dr. Michael A. Sørensen, Dr. Sofie V. Nielsen, and Dr. Martin Willemoës for helpful discussions and comments on the manuscript.

\section{Competing interests}

No competing interests declared.

\section{Author contributions}

C.K., C.H., M.K., S.K.G., M.H.L., I.J. conducted the experiments. C.K., C.H., I.J., M.K., M.H.L, B.B.K, J.V.J., and R.H.P. analyzed the data. C.K., J.V.J., H.N.B., M.H.L., J.R.W. and R.H.P. designed the experiments. J.R.W. and R.H.P. conceived the study. C.K., J.R.W. and R.H.P. wrote the paper.

\section{Funding}

R.H.P. is supported by grants from the Lundbeck Foundation, the Novo Nordisk Foundation, the A.P. Møller Foundation, and the Danish Council for Independent Research (Technology and Production Sciences). R.H.P. and B.B.K. are supported by the Novo Nordisk Foundation REPIN programme. 


\section{References}

1. Benner SA, Ricardo A, Carrigan MA. Is there a common chemical model for life in the universe? Curr Opin Chem Biol. 2004;8(6):672-89.

2. Zhang W, Needham DL, Coffin M, Rooker A, Hurban P, Tanzer MM, et al. Microarray analyses of the metabolic responses of Saccharomyces cerevisiae to organic solvent dimethyl sulfoxide. J Ind Microbiol Biotechnol. 2003;30(1):57-69.

3. Krumbiegel P. Large deuterium isotope effects and their use: a historical review. Isotopes Environ Health Stud. 2011;47(1):1-17.

4. Kresheck GC, Schneider H, Scheraga HA. The effect of D2-O on the thermal stability of proteins. Thermodynamic parameters for the transfer of model compounds from H2-O to D2-O. J Phys Chem. 1965;69(9):3132-44.

5. Kushner DJ, Baker A, Dunstall TG. Pharmacological uses and perspectives of heavy water and deuterated compounds. Can J Physiol Pharmacol. 1999;77(2):79-88.

6. Wallace SA, Mathur JN, Allen BJ. The influence of heavy water on boron requirements for neutron capture therapy. Med Phys. 1995;22(5):585-90.

7. Baum D, Dobbing J, Coward WA. Deuterium method for measuring milk intake in babies. Lancet. 1979;2(8137):309.

8. Lifson N, Gordon GB, McClintock R. Measurement of total carbon dioxide production by means of D2O18. 1955. Obes Res. 1997;5(1):78-84.

9. Rodewald LE, Maiman LA, Foye HR, Borch RF, Forbes GB. Deuterium oxide as a tracer for measurement of compliance in pediatric clinical drug trials. J Pediatr. 1989;114(5):885-91.

10. Pittendrigh CS, Caldarola PC, Cosbey ES. A differential effect of heavy water on temperaturedependent and temperature-compensated aspects of circadian system of Drosophila pseudoobscura. Proc Natl Acad Sci U S A. 1973;70(7):2037-41.

11. Adams WH, Adams DG. Effects of deuteration on hematopoiesis in the mouse. J Pharmacol Exp Ther. 1988;244(2):633-9.

12. Katz JJ, Crespi HL, Czajka DM, Finkel AJ. Course of deuteriation and some physiological effects of deuterium in mice. Am J Physiol. 1962;203:907-13.

13. Gross PR, Spindel W. Mitotic arrest by deuterium oxide. Science. 1960;131:37-8.

14. Takahashi TC, Sato H. Effects of heavy water (D2O) on the length of the mitotic period in developing sea urchin eggs. Cell Struct Funct. 1983;8(4):357-65.

15. Lamprecht J, Schroeter D, Paweletz N. Mitosis arrested by deuterium oxide. Light microscopic, immunofluorescence and ultrastructural characterization. Eur J Cell Biol. 1990;51(2):303-12.

16. Lamprecht J, Schroeter D, Paweletz N. Derangement of microtubule arrays in interphase and mitotic PtK2 cells treated with deuterium oxide (heavy water). J Cell Sci. 1991;98 ( Pt 4):463-73. 
17. Paliy $\mathrm{O}$, Bloor D, Brockwell D, Gilbert P, Barber J. Improved methods of cultivation and production of deuteriated proteins from E. coli strains grown on fully deuteriated minimal medium. J Appl Microbiol. 2003;94(4):580-6.

18. Vanatalu K, Paalme T, Vilu R, Burkhardt N, Junemann R, May R, et al. Large-scale preparation of fully deuterated cell components. Ribosomes from Escherichia coli with high biological activity. Eur J Biochem. 1993;216(1):315-21.

19. Opitz C, Ahrne E, Goldie KN, Schmidt A, Grzesiek S. Deuterium induces a distinctive Escherichia coli proteome that correlates with the reduction in growth rate. J Biol Chem. 2019;294(7):2279-92.

20. Bartel B, Varshavsky A. Hypersensitivity to heavy water: a new conditional phenotype. Cell. 1988;52(6):935-41.

21. Li X, Snyder MP. Yeast longevity promoted by reversing aging-associated decline in heavy isotope content. NPJ Aging Mech Dis. 2016;2:16004.

22. Izzo V, Fornili SL, Cordone L. Thermal denaturation of B. subtilis DNA in $\mathrm{H} 2 \mathrm{O}$ and $\mathrm{D} 2 \mathrm{O}$ observed by electron microscopy. Nucleic Acids Res. 1975;2(10):1805-10.

23. Cupane A, Vitrano E, San Biago PL, Madonia F, Palma MU. Thermal stability of poly(A) and poly(U) complexes in $\mathrm{H} 2 \mathrm{O}$ and D2O: isotopic effects on critical temperatures and transition widths. Nucleic Acids Res. 1980;8(18):4283-303.

24. Hattori A, Crespi HL, Katz JJ. Effect of side-chain deuteration on protein stability. Biochemistry. 1965;4(7):1213-25.

25. Makhatadze GI, Clore GM, Gronenborn AM. Solvent isotope effect and protein stability. Nat Struct Biol. 1995;2(10):852-5.

26. Chellgren BW, Creamer TP. Effects of $\mathrm{H} 2 \mathrm{O}$ and $\mathrm{D} 2 \mathrm{O}$ on polyproline II helical structure. J Am Chem Soc. 2004;126(45):14734-5.

27. Brown CR, Hong-Brown LQ, Biwersi J, Verkman AS, Welch WJ. Chemical chaperones correct the mutant phenotype of the delta F508 cystic fibrosis transmembrane conductance regulator protein. Cell Stress Chaperones. 1996;1(2):117-25.

28. Unno K, Okada S. Deuteration causes the decreased induction of heat-shock proteins and increased sensitivity to heat denaturation of proteins in Chlorella. Plant Cell Physiol. 1994;35(2):197-202.

29. Hoffman CS, Wood V, Fantes PA. An Ancient Yeast for Young Geneticists: A Primer on the Schizosaccharomyces pombe Model System. Genetics. 2015;201(2):403-23.

30. Perez P, Cortes JC, Martin-Garcia R, Ribas JC. Overview of fission yeast septation. Cell Microbiol. 2016;18(9):1201-7.

31. Simanis V. Pombe's thirteen - control of fission yeast cell division by the septation initiation network. J Cell Sci. 2015;128(8):1465-74.

32. Marks J, Hagan IM, Hyams JS. Growth polarity and cytokinesis in fission yeast: the role of the cytoskeleton. J Cell Sci Suppl. 1986;5:229-41. 
33. Hochuli M, Szyperski T, Wuthrich K. Deuterium isotope effects on the central carbon metabolism of Escherichia coli cells grown on a D2O-containing minimal medium. J Biomol NMR. 2000;17(1):3342 .

34. Ardenkjaer-Larsen JH, Fridlund B, Gram A, Hansson G, Hansson L, Lerche MH, et al. Increase in signal-to-noise ratio of $>10,000$ times in liquid-state NMR. Proc Natl Acad Sci U S A. 2003;100(18):10158-63.

35. Lerche MH, Yigit D, Frahm AB, Ardenkjaer-Larsen JH, Malinowski RM, Jensen PR. Stable IsotopeResolved Analysis with Quantitative Dissolution Dynamic Nuclear Polarization. Anal Chem. 2018;90(1):674-8.

36. Cordeiro AT, Godoi PH, Silva CH, Garratt RC, Oliva G, Thiemann OH. Crystal structure of human phosphoglucose isomerase and analysis of the initial catalytic steps. Biochim Biophys Acta. 2003;1645(2):117-22.

37. Tsai CS, Ye HG, Shi JL. Carbon-13 NMR studies and purification of gluconate pathway enzymes from Schizosaccharomyces pombe. Arch Biochem Biophys. 1995;316(1):155-62.

38. Corkins ME, Wilson S, Cocuron JC, Alonso AP, Bird AJ. The gluconate shunt is an alternative route for directing glucose into the pentose phosphate pathway in fission yeast. $\mathrm{J}$ Biol Chem. 2017;292(33):13823-32.

39. Junemann R, Wadzack J, Triana-Alonso FJ, Bittner JU, Caillet J, Meinnel T, et al. In vivo deuteration of transfer RNAs: overexpression and large-scale purification of deuterated specific tRNAs. Nucleic Acids Res. 1996;24(5):907-13.

40. Chatr-Aryamontri A, Oughtred R, Boucher L, Rust J, Chang C, Kolas NK, et al. The BioGRID interaction database: 2017 update. Nucleic Acids Res. 2017;45(D1):D369-D379.

41. Ma Y, Sugiura R, Koike A, Ebina H, Sio SO, Kuno T. Transient receptor potential (TRP) and Cch1Yam8 channels play key roles in the regulation of cytoplasmic $\mathrm{Ca} 2+$ in fission yeast. PLoS One. 2011;6(7):e22421.

42. Deng L, Sugiura R, Takeuchi M, Suzuki M, Ebina H, Takami T, et al. Real-time monitoring of calcineurin activity in living cells: evidence for two distinct $\mathrm{Ca} 2+$-dependent pathways in fission yeast. Mol Biol Cell. 2006;17(11):4790-800.

43. Soto T, Villar-Tajadura MA, Madrid M, Vicente J, Gacto M, Perez P, et al. Rga4 modulates the activity of the fission yeast cell integrity MAPK pathway by acting as a Rho2 GTPase-activating protein. J Biol Chem. 2010;285(15):11516-25.

44. Villar-Tajadura MA, Coll PM, Madrid M, Cansado J, Santos B, Perez P. Rga2 is a Rho2 GAP that regulates morphogenesis and cell integrity in S. pombe. Mol Microbiol. 2008;70(4):867-81.

45. Ryan CJ, Roguev A, Patrick K, Xu J, Jahari H, Tong Z, et al. Hierarchical modularity and the evolution of genetic interactomes across species. Mol Cell. 2012;46(5):691-704.

46. Madrid M, Jimenez R, Sanchez-Mir L, Soto T, Franco A, Vicente-Soler J, et al. Multiple layers of regulation influence cell integrity control by the PKC ortholog Pck2 in fission yeast. J Cell Sci. 2015;128(2):266-80. 
47. Madrid M, Vazquez-Marin B, Soto T, Franco A, Gomez-Gil E, Vicente-Soler J, et al. Differential functional regulation of protein kinase $\mathrm{C}$ (PKC) orthologs in fission yeast. J Biol Chem. 2017;292(27):11374-87.

48. Levin DE. Regulation of cell wall biogenesis in Saccharomyces cerevisiae: the cell wall integrity signaling pathway. Genetics. 2011;189(4):1145-75.

49. Sheu SY, Schlag EW, Selzle HL, Yang DY. Molecular dynamics of hydrogen bonds in protein-D2O: the solvent isotope effect. J Phys Chem A. 2008;112(5):797-802.

50. Lopez MM, Makhatadze GI. Solvent isotope effect on thermodynamics of hydration. Biophys Chem. 1998;74(2):117-25.

51. Das DK, Mondal T, Mandal U, Bhattacharyya K. Probing deuterium isotope effect on structure and solvation dynamics of human serum albumin. Chemphyschem. 2011;12(4):814-22.

52. Efimova YM, Haemers S, Wierczinski B, Norde W, van Well AA. Stability of globular proteins in H2O and D2O. Biopolymers. 2007;85(3):264-73.

53. Krantz BA, Moran LB, Kentsis A, Sosnick TR. D/H amide kinetic isotope effects reveal when hydrogen bonds form during protein folding. Nat Struct Biol. 2000;7(1):62-71.

54. Krantz BA, Srivastava AK, Nauli S, Baker D, Sauer RT, Sosnick TR. Understanding protein hydrogen bond formation with kinetic H/D amide isotope effects. Nat Struct Biol. 2002;9(6):458-63.

55. Unno K, Kishido T, Morioka M, Okada S, Oku N. Increased expression of Hsp70 for resistance to deuterium oxide in a yeast mutant cell line. Biol Pharm Bull. 2003;26(6):799-802.

56. Whipple JM, Lane EA, Chernyakov I, D'Silva S, Phizicky EM. The yeast rapid tRNA decay pathway primarily monitors the structural integrity of the acceptor and T-stems of mature tRNA. Genes Dev. 2011;25(11):1173-84.

57. Svenningsen SL, Kongstad M, Stenum TS, Munoz-Gomez AJ, Sorensen MA. Transfer RNA is highly unstable during early amino acid starvation in Escherichia coli. Nucleic Acids Res. 2017;45(2):793804.

58. Estruch F. Stress-controlled transcription factors, stress-induced genes and stress tolerance in budding yeast. FEMS Microbiol Rev. 2000;24(4):469-86.

59. Herrero E, Ros J, Belli G, Cabiscol E. Redox control and oxidative stress in yeast cells. Biochim Biophys Acta. 2008;1780(11):1217-35.

60. Chen D, Toone WM, Mata J, Lyne R, Burns G, Kivinen K, et al. Global transcriptional responses of fission yeast to environmental stress. Mol Biol Cell. 2003;14(1):214-29.

61. Kriegenburg F, Poulsen EG, Koch A, Kruger E, Hartmann-Petersen R. Redox control of the ubiquitinproteasome system: from molecular mechanisms to functional significance. Antioxid Redox Signal. 2011;15(8):2265-99.

62. Zaitsevskaya-Carter T, Cooper JA. Spm1, a stress-activated MAP kinase that regulates morphogenesis in S.pombe. EMBO J. 1997;16(6):1318-31. 
63. Toda T, Dhut S, Superti-Furga G, Gotoh Y, Nishida E, Sugiura R, et al. The fission yeast pmk1+ gene encodes a novel mitogen-activated protein kinase homolog which regulates cell integrity and functions coordinately with the protein kinase C pathway. Mol Cell Biol. 1996;16(12):6752-64.

64. Cadou A, Couturier A, Le GC, Soto T, Miklos I, Sipiczki M, et al. Kin1 is a plasma membraneassociated kinase that regulates the cell surface in fission yeast. Mol Microbiol. 2010;77(5):1186-202.

65. Lee ME, Rusin SF, Jenkins N, Kettenbach AN, Moseley JB. Mechanisms Connecting the Conserved Protein Kinases Ssp1, Kin1, and Pom1 in Fission Yeast Cell Polarity and Division. Curr Biol. 2018;28(1):84-92.

66. Hohmann S. Osmotic stress signaling and osmoadaptation in yeasts. Microbiol Mol Biol Rev. 2002;66(2):300-72.

67. Brooks SC. Osmotic effects of deuterium oxide (heavy water) on living cells. Science. 1937;86(2239):497-8.

68. Andjus PR, Kataev AA, Alexandrov AA, Vucelic D, Berestovsky GN. D2O-induced ion channel activation in Characeae at low ionic strength. J Membr Biol. 1994;142(1):43-53.

69. Kock C, Dufrene YF, Heinisch JJ. Up against the wall: is yeast cell wall integrity ensured by mechanosensing in plasma membrane microdomains? Appl Environ Microbiol. 2015;81(3):806-11.

70. Beranova L, Humpolickova J, Sykora J, Benda A, Cwiklik L, Jurkiewicz P, et al. Effect of heavy water on phospholipid membranes: experimental confirmation of molecular dynamics simulations. Phys Chem Chem Phys. 2012;14(42):14516-22.

71. Gardner KH, Kay LE. The use of $2 \mathrm{H}, 13 \mathrm{C}, 15 \mathrm{~N}$ multidimensional NMR to study the structure and dynamics of proteins. Annu Rev Biophys Biomol Struct. 1998;27:357-406.

72. Claassen DO, Carroll B, De Boer LM, Wu E, Ayyagari R, Gandhi S, et al. Indirect tolerability comparison of Deutetrabenazine and Tetrabenazine for Huntington disease. J Clin Mov Disord. 2017;4:3.

73. Mullard A. Deuterated drugs draw heavier backing. Nat Rev Drug Discov. 2016;15(4):219-21.

74. Timmins GS. Deuterated drugs; updates and obviousness analysis. Expert Opin Ther Pat. 2017;27(12):1353-61.

75. Schmidt C. First deuterated drug approved. Nat Biotechnol. 2017;35(6):493-4.

76. Kim DU, Hayles J, Kim D, Wood V, Park HO, Won M, et al. Analysis of a genome-wide set of gene deletions in the fission yeast Schizosaccharomyces pombe. Nat Biotechnol. 2010;28(6):617-23.

77. Huang J, Huang Y, Yu H, Subramanian D, Padmanabhan A, Thadani R, et al. Nonmedially assembled F-actin cables incorporate into the actomyosin ring in fission yeast. J Cell Biol. 2012;199(5):831-47.

78. Sato M, Toya M, Toda T. Visualization of fluorescence-tagged proteins in fission yeast: the analysis of mitotic spindle dynamics using GFP-tubulin under the native promoter. Methods Mol Biol. 2009;545:185-203.

79. Petersen J, Russell P. Growth and the Environment of Schizosaccharomyces pombe. Cold Spring Harb Protoc. 2016;2016(3):db. 
80. Andersen KM, Jensen C, Kriegenburg F, Lauridsen AM, Gordon C, Hartmann-Petersen R. Txl1 and Txc1 are co-factors of the 26S proteasome in fission yeast. Antioxid Redox Signal. 2011;14(9):16018.

81. Graub R, Hilti N, Niederberger C, Schweingruber ME. Ksg1, a homologue of the phosphoinositidedependent protein kinase 1, controls cell wall integrity in Schizosaccharomyces pombe. J Basic Microbiol. 2003;43(6):473-82.

82. Jourdain I, Dooley HC, Toda T. Fission yeast sec3 bridges the exocyst complex to the actin cytoskeleton. Traffic. 2012;13(11):1481-95.

83. Schindelin J, Arganda-Carreras I, Frise E, Kaynig V, Longair M, Pietzsch T, et al. Fiji: an open-source platform for biological-image analysis. Nat Methods. 2012;9(7):676-82.

84. Kampmeyer C, Karakostova A, Schenstrom SM, Abildgaard AB, Lauridsen AM, Jourdain I, et al. The exocyst subunit Sec3 is regulated by a protein quality control pathway. J Biol Chem. 2017;292(37):15240-53.

85. Wishart DS, Feunang YD, Marcu A, Guo AC, Liang K, Vazquez-Fresno R, et al. HMDB 4.0: the human metabolome database for 2018. Nucleic Acids Res. 2018;46(D1):D608-D617.

86. Lyne R, Burns G, Mata J, Penkett CJ, Rustici G, Chen D, et al. Whole-genome microarrays of fission yeast: characteristics, accuracy, reproducibility, and processing of array data. BMC Genomics. 2003;4(1):27.

87. Feng J, Meyer CA, Wang Q, Liu JS, Shirley L, X, Zhang Y. GFOLD: a generalized fold change for ranking differentially expressed genes from RNA-seq data. Bioinformatics. 2012;28(21):2782-8.

88. Love MI, Huber W, Anders S. Moderated estimation of fold change and dispersion for RNA-seq data with DESeq2. Genome Biol. 2014;15(12):550.

89. Marinova IN, Engelbrecht J, Ewald A, Langholm LL, Holmberg C, Kragelund BB, et al. Single site suppressors of a fission yeast temperature-sensitive mutant in cdc48 identified by whole genome sequencing. PLoS One. 2015;10(2):e0117779.

90. Bolger AM, Lohse M, Usadel B. Trimmomatic: a flexible trimmer for Illumina sequence data. Bioinformatics. 2014;30(15):2114-20.

91. Li H, Durbin R. Fast and accurate long-read alignment with Burrows-Wheeler transform. Bioinformatics. 2010;26(5):589-95.

92. Lunter G, Goodson M. Stampy: a statistical algorithm for sensitive and fast mapping of Illumina sequence reads. Genome Res. 2011;21(6):936-9.

93. McKenna A, Hanna M, Banks E, Sivachenko A, Cibulskis K, Kernytsky A, et al. The Genome Analysis Toolkit: a MapReduce framework for analyzing next-generation DNA sequencing data. Genome Res. 2010;20(9):1297-303.

94. Cibulskis K, Lawrence MS, Carter SL, Sivachenko A, Jaffe D, Sougnez C, et al. Sensitive detection of somatic point mutations in impure and heterogeneous cancer samples. Nat Biotechnol. 2013;31(3):213-9. 
95. Garrison E, Marth G. Haplotype-based variant detection from short-read sequencing. arXiv. $2012 ; 1207.3907$.

96. Wang K, Li M, Hakonarson H. ANNOVAR: functional annotation of genetic variants from highthroughput sequencing data. Nucleic Acids Res. 2010;38(16):e164.

97. Vjestica A, Zhang D, Liu J, Oliferenko S. Hsp70-Hsp40 chaperone complex functions in controlling polarized growth by repressing Hsf1-driven heat stress-associated transcription. PLoS Genet. 2013;9(10):e1003886.

98. Poulsen EG, Kampmeyer C, Kriegenburg F, Johansen JV, Hofmann K, Holmberg C, et al. UBL/BAGdomain co-chaperones cause cellular stress upon overexpression through constitutive activation of Hsf1. Cell Stress Chaperones. 2017;22(1):143-54. 
Table 1

\begin{tabular}{|c|c|c|}
\hline \multicolumn{3}{|c|}{ Gene deletions scored as $\mathrm{D}_{2} \mathrm{O}$ hypersensitive in high-throughput screen } \\
\hline Systematic ID & Gene name & Function \\
\hline SPAC13G7.03 & upf3 & up-frameshift suppressor 3 family protein \\
\hline SPBC1539.08 & $\operatorname{arf6}$ & ADP-ribosylation factor, Arf family Arf6 \\
\hline SPAC2F3.02 & - & ER protein translocation subcomplex subunit \\
\hline SPAC328.01C & msn5 & karyopherin/importin beta family nuclear import/export signal receptor \\
\hline SPAPB2B4.02 & $\operatorname{grx} 5$ & mitochondrial $[2 \mathrm{Fe}-2 \mathrm{~S}]$ cluster assembly \& transfer glutaredoxin Grx 5 \\
\hline SPAC4D7.03 & рор2 & F-box/WD repeat protein Pop2 \\
\hline SPCC970.10c & brl2 & ubiquitin-protein ligase E3 Brl2 \\
\hline SPBC18H10.06C & swd2 & Set1C complex subunit \\
\hline SPBC19C7.02 & ubr1 & N-end-recognizing protein E3 Ubr1 \\
\hline SPAC17H9.10c & $d d b 1$ & Cul4-RING E3 adaptor Ddb1 \\
\hline SPAC26H5.05 & mga2 & IPT/TIG ankyrin repeat transcription regulator of fatty acid synthesis \\
\hline SPBC106.10 & pka1 & cAMP-dependent protein kinase catalytic subunit Pka1 \\
\hline SPAC6F6.01 & $\operatorname{cch} 1$ & plasma membrane calcium ion import channel Cch1 \\
\hline SPACЗН8.02 & $\operatorname{csr} 102$ & Sec14 family, phospholipid-intermembrane transfer protein Csr102 \\
\hline SPBC13G1.08c & ash2 & Ash2-trithorax family protein \\
\hline SPCP1E11.06 & apl4 & AP-1 adaptor complex gamma subunit Apl4 \\
\hline SPAC10F6.13c & caa1 & cytoplasmic aspartate aminotransferase Caa1 \\
\hline SPBC23G7.08c & rga7 & RhoGAP, GTPase activating protein Rga7 \\
\hline SPBC27B12.08 & $\operatorname{sip} 1$ & Pof6 interacting protein Sip1, AP-1 accessory protein \\
\hline SPBC21C3.20c & git1 & $\mathrm{C} 2$ domain protein Git1 \\
\hline SPAC806.07 & $n d k 1$ & nucleoside diphosphate kinase Ndk1 \\
\hline SPAC644.06c & $c d r 1$ & NIM1 family serine/threonine protein kinase Cdr1/Nim1 \\
\hline SPBC16E9.13 & ksp1 & serine/threonine protein kinase Ksp1 \\
\hline SPCC1739.14 & nрp106 & nucleoporin Npp106 \\
\hline SPAC7D4.06c & $\operatorname{alg} 3$ & dolichol-P-Man-dependent alpha(1-3) mannosyltransferase Alg3 \\
\hline SPBC3B9.11c & $c t f 1$ & mRNA cleavage and polyadenylation specificity factor subunit Ctfl \\
\hline SPAC2F7.07c & $\operatorname{cph} 2$ & Clr6 histone deacetylase associated PHD protein Cph2 \\
\hline SPBC16E9.08 & mср4 & prospore membrane protein Mcp4/Mug101 \\
\hline SPAC926.03 & rlc1 & myosin II regulatory light chain Rlc1 \\
\hline SPBC13G1.03c & pex14 & peroxisomal docking protein Pex14 \\
\hline SPBC776.15c & $k d g 2$ & dihydrolipoamide S-succinyltransferase Kdg2 \\
\hline SPAC513.03 & $m f m 2$ & M-factor precursor Mfm2 \\
\hline SPAC26F1.04C & etr1* & enoyl-[acyl-carrier protein] reductase \\
\hline SPBP8B7.11 & $n x t 3$ & ubiquitin protease cofactor $\mathrm{Nxt} 3$ \\
\hline SPAC12B10.12c & rhp41 & DNA repair protein $\mathrm{Rhp} 41$ \\
\hline SPCC777.10c & $u b c 12$ & NEDD8-conjugating enzyme Ubc12 \\
\hline SPAC4H3.13 & pcc1 & EKC/KEOPS complex subunit Pcc1 \\
\hline SPAC5D6.05 & med18 & mediator complex subunit Med18 \\
\hline SPCC970.06 & erv29 & COP II adaptor Erv29 \\
\hline
\end{tabular}

*: Upregulated in RNA seq. at 24 hours in $\mathrm{D}_{2} \mathrm{O}$. 
Table 2

Mutect 2 predicted genome sequence differences in the hwr strains

\begin{tabular}{llllll}
\hline Mutant & Chr.* & Nucleotide change* & Location & Gene & Type \\
\hline hwr1-1 & II & A4313777del & exon & pek1 & frameshift \\
$h w r 1-1$ & III & G2337547A & exon & trm72 & missense (G253E) \\
$h w r 2-1$ & I & 613724CTATGTTCAAGins & exon & mkh1 & frameshift \\
$h w r 2-1$ & I & 1670566Tins & splicing & gta2 & - \\
$h w r 2-1$ & I & T5448804del & 5' UTR & SPAC1039.02\# & - \\
$h w r 3-1$ & I & G3273325C & ncRNA & SPNCRNA.899 & - \\
$h w r 3-1$ & II & C2310230T & exon & pck2 & missense (G870S) \\
\hline
\end{tabular}

831 *: Chr.: chromosome, del: deletion, ins: insertion; \#: Downregulated in RNA seq. after 5 hours in $\mathrm{D}_{2} \mathrm{O}$. 


\section{Figure legends}

\section{Figure $1-\mathrm{D}_{2} \mathrm{O}$ inhibits cell growth.}

(A) Cell growth of wild type (no marker) S. pombe cells in rich medium was followed by measuring the turbidity of the culture at the indicated concentrations of $\mathrm{D}_{2} \mathrm{O}$. The error bars indicate the standard deviation (n=3). (B) From growth experiments as shown in (A), the doubling time of wild type $S$. pombe cells in exponential phase was determined at the indicated concentrations of $\mathrm{D}_{2} \mathrm{O}$. The error bars indicate the standard deviation $(n=3)$. (C) A close up of the growth curves shown in (A) during the first three hours of culturing at the indicated concentrations of $\mathrm{D}_{2} \mathrm{O}$. Note that the growth retardation caused by $\mathrm{D}_{2} \mathrm{O}$ occurs rapidly. The error bars indicate the standard deviation ( $\mathrm{n}=3$ ). (D) The viability of wild type cells grown at $0 \%$ and $100 \% \mathrm{D}_{2} \mathrm{O}$ was determined by VitaBright staining and quantified by automated fluorescence microscopy. The error bars indicate the standard deviation $(n=3)$. (E) The growth of wild type cells, pre-incubated for 5 hours at $0,50,75$ or $100 \% \mathrm{D}_{2} \mathrm{O}$ in liquid YES media, was compared by serial diluting and spotting onto solid rich media agar plates with the indicated concentrations of $\mathrm{D}_{2} \mathrm{O}$ at $30^{\circ} \mathrm{C}$. (F) The growth of wild type cells was compared on media prepared with $\mathrm{D}_{2} \mathrm{O}$ or $\mathrm{H}_{2} \mathrm{O}$ with either hydrogenated glucose $(\mathrm{Glu}(\mathrm{H})$ ) or deuterated glucose $(\mathrm{Glu}$ (D)) by serial diluting and spotting onto solid rich media or synthetic minimal media agar plates at $30^{\circ} \mathrm{C}$.

Figure $2-\mathrm{D}_{2} \mathrm{O}$ affects cell morphology and causes cell septation defects.

(A) Wild type cells grown at $0 \%$ and $100 \% \mathrm{D}_{2} \mathrm{O}$ for the indicated times were stained with calcofluor (to mark the septa) and Hoechst (to mark the nucleus) and analyzed by microscopy. Note that the thickness of the septa is increased in the presence of $\mathrm{D}_{2} \mathrm{O}$. Bar $=5 \mu \mathrm{m}$. (B) The percentages of septated cells (septation index) and of septated cells with multiple septa were determined after 5 and 24 hours at the indicated concentrations of $\mathrm{D}_{2} \mathrm{O}$. The error bars indicate the standard deviation $(\mathrm{n}=4)$. (C) Transmission electron microscopy images of wild type cells after 24 hours in $0 \%$ or $100 \% \mathrm{D}_{2} \mathrm{O}$ YES medium. Note the irregular septa and thickening of the cell wall (black arrow head). Bar $=5 \mu \mathrm{m}$. (D) Transmission electron microscopy images of wild type cells after 24 hours in $0 \%$ or $100 \% \mathrm{D}_{2} \mathrm{O}$ YES medium as in panel A. Bar $=5 \mu \mathrm{m}$. (E) Cell lysis of wild type (no marker) cells grown at the indicated $\mathrm{D}_{2} \mathrm{O}$ concentrations for 24 hours was recorded over time by measuring turbidity of cultures treated with $\beta$-glucanase (in water). The error bars indicate the standard deviation $(n=4)$.

Figure $3-\mathrm{D}_{2} \mathrm{O}$ inhibits glucose metabolism.

(A) Hyperpolarized ${ }^{13} \mathrm{C}$ NMR spectrum of cellular metabolite extract following incubation with the isotope labelled glucose tracer for 10 minutes in $\mathrm{D}_{2} \mathrm{O}$ buffer (red spectrum) and $\mathrm{H}_{2} \mathrm{O}$ buffer (black spectrum). Red insert shows a zoom-in on the carbonyl region showing gluconate (GA) and 6phosphogluconate (6PGA). The asterisk marks an unidentified metabolite. Blue insert shows a zoomin on the aliphatic sugar region, revealing a multiplet centred at $61.2 \mathrm{ppm}$ originating from $6-{ }^{13} \mathrm{C}$ glucose. The multiplet at $62.8 \mathrm{ppm}$ originates from the $\alpha$-form of glucose- 6 -phosphate $(\alpha-\mathrm{G} 6 \mathrm{P})$ in the spectrum from the $\mathrm{D}_{2} \mathrm{O}$ experiments (red) and from the $\beta$-form of glucose-6-phosphate $(\beta-\mathrm{G} 6 \mathrm{P})$ in 
the spectrum from the $\mathrm{H}_{2} \mathrm{O}$ experiments (black). (B) Quantitative difference between accumulated glucose-6-phosphate (G6P) signal in $\mathrm{D}_{2} \mathrm{O}$ and $\mathrm{H}_{2} \mathrm{O}$ exposed cells following incubation with ${ }^{13} \mathrm{C}_{6}-\mathrm{d}_{7}$ labelled glucose for 10 minutes. The error bars indicate the standard deviation $(n=4)$. (C) Glucose metabolic pathways when $S$. pombe cells are exposed to $\mathrm{D}_{2} \mathrm{O}$ and $\mathrm{H}_{2} \mathrm{O}$. Metabolites identified in panel A are highlighted in red. Glucose in its $\beta$-form is in both $\mathrm{D}_{2} \mathrm{O}$ and $\mathrm{H}_{2} \mathrm{O}$ buffers converted into gluconate (GA) and further into 6-phosphogluconate (6PGA) in the pentose phosphate pathway (PPP). In $\mathrm{D}_{2} \mathrm{O}$, the $\alpha$-form of glucose-6-phosphate ( $\left.\alpha-\mathrm{G} 6 \mathrm{P}\right)$ is accumulating whereas the $\beta$-form is metabolized more rapidly. Contrary, in $\mathrm{H}_{2} \mathrm{O}$, no accumulation of $\alpha-\mathrm{G} 6 \mathrm{P}$ can be detected. An explanation for this difference is an altered activity of glucose-6-phosphate isomerase (GPI, EC 5.3.1.9) when the cells are exposed to $\mathrm{D}_{2} \mathrm{O}$. This enzyme catalyzes the isomerization reactions between $\alpha-\mathrm{G} 6 \mathrm{P}$ and $\beta-\mathrm{G} 6 \mathrm{P}, \alpha-\mathrm{G} 6 \mathrm{P}$ and $\beta-\mathrm{F} 6 \mathrm{P}$, and $\beta-\mathrm{G} 6 \mathrm{P}$ and $\beta-\mathrm{F} 6 \mathrm{P}$ (blue reactions).

Figure 4 - RNA sequencing of cells treated with $\mathrm{D}_{2} \mathrm{O}$.

(A) Total RNA was sequenced from wild type (no marker) cells that were either untreated $\left(0 \% \mathrm{D}_{2} \mathrm{O}\right)$ or treated with $100 \% \mathrm{D}_{2} \mathrm{O}$ for 5 or 24 hours in quadruplicates. Heatmap showing hierarchical clustering on the Euclidian distances between full set of gene counts for all samples (after DESeq2's own $\log$ transformation and variance stabilization). (B) Plot showing the first two principal components from a principal component analysis (PCA) on the full set of gene counts. (C) Heatmap of CESR genes as defined by Chen et al. for $\mathrm{D}_{2} \mathrm{O}$ regulated genes, mas5 $\Delta$, ssa2 $\Delta$, heat shock [97], sty $1 \Delta$, atf1 $[60]$, and bag101 overexpression (OE) [98]. The combined datasets were quantile normalized to make them comparable. Color key including value frequency is shown next to the heatmap. Note that the $\mathrm{D}_{2} \mathrm{O}$ response resembles the heat stress, mas5 $\Delta$, ssa2 $\Delta$ and bag101 OE response, but not that in the other strains. (D) Plot showing the first two principal components from a principal component analysis (PCA) on the same data shown in (C). (E) The growth at $30^{\circ} \mathrm{C}$ of wild type (no marker) cells that were either untreated (control) or subjected to a 30 minute heat shock at $43{ }^{\circ} \mathrm{C}$ was compared in the presence of the indicated concentrations of $\mathrm{D}_{2} \mathrm{O}$ by serial diluting and spotting onto solid rich media. (F) The growth at $30^{\circ} \mathrm{C}$ of wild type cells that were either untreated (control) or exposed to $0.07 \mathrm{mM} \mathrm{H}_{2} \mathrm{O}_{2}$ for 1 hour, was compared in the presence of the indicated concentrations of $\mathrm{D}_{2} \mathrm{O}$ by serial diluting and spotting onto solid rich media. $(\mathrm{G})$ Wild type cells that were either untreated (control) or subjected to 5 hours incubation in rich medium containing 100\% $\mathrm{D}_{2} \mathrm{O}$ were challenged with the indicated heat shock conditions prior to spotting onto solid rich media at $30^{\circ} \mathrm{C}$. (H) The growth of wild type cells that were either untreated (control) or subjected to 5 hours incubation in rich medium containing $100 \% \mathrm{D}_{2} \mathrm{O}$ was compared in the presence of the indicated concentrations of $\mathrm{H}_{2} \mathrm{O}_{2}$ by serial diluting and spotting onto solid rich media at $30^{\circ} \mathrm{C}$.

Figure $5-\mathrm{D}_{2} \mathrm{O}$ sensitive and $\mathrm{D}_{2} \mathrm{O}$ resistant $\mathrm{S}$. pombe mutants.

(A) The growth of a 3 marker wild type strain and the otherwise isogenic caa1 $\Delta$ were compared in the presence of the indicated concentrations of $\mathrm{D}_{2} \mathrm{O}$ by serial diluting and spotting onto solid rich media at $30^{\circ} \mathrm{C}$. (B) The growth of a 3 marker wild type strain and the otherwise isogenic deletion mutants were compared in the presence of the indicated concentrations of $\mathrm{D}_{2} \mathrm{O}$ by serial diluting and spotting onto solid rich media at $30^{\circ} \mathrm{C}$. (C) Schematic representation of pairwise genetic or physical 
915 interactions listed in the BioGRID database (version 3.4.164) between the deleted genes/proteins in 916 the isolated $\mathrm{D}_{2} \mathrm{O}$ hypersensitive strains (grey) and $\mathrm{D}_{2} \mathrm{O}$ tolerant strain (Pmk1, black).

Figure 6 - $\mathrm{D}_{2} \mathrm{O}$ activates the cell integrity pathway.

919 (A) The growth of 3 marker wild type cells and the isolated $h w r$ mutants was compared by serial diluting and spotting onto solid rich media agar plates. (B) The cell integrity pathway in S. pombe cells as described by Madrid et al. [47]. The pathway is known to be activated by salt stress or cell wall damaging agents (red arrows), and consists of small GTPases that activate Pck1 and Pck2. In turn, this leads to activation of Mkh1, Pek1 and finally of the MAPK Pmk1 which ultimately triggers increased cell wall synthesis. Rga7 functions as a Rho2 GAP that limits signaling [43]. The signaling components identified with mutations in the $h w r$ strains are shown in green. The $\mathrm{D}_{2} \mathrm{O}$ hypersensitive phenotype observed for the rga7 $\Delta$ strain is shown in red. (C) The growth of 3 marker wild type cells and the indicated mutants in the cell integrity pathway was compared by serial diluting and spotting onto solid rich media agar plates at $25{ }^{\circ} \mathrm{C}$. (D) Wild type cells ( 3 marker) at $100 \% \mathrm{D}_{2} \mathrm{O}$ for 24 hours were stained with calcofluor and analyzed by microscopy. Bar $=5 \mu \mathrm{m}$. (E) Whole cell lysates of wild type cells expressing HA-tagged Pmk1 were analyzed by SDS-PAGE and Western blotting using antibodies to phosphorylated Pmk1 (P-p44/42), the HA-tag on Pmk1 and, as a loading control, to $\alpha$ tubulin. Note that the level of phosphorylated Pmk1 is increased in response to $\mathrm{D}_{2} \mathrm{O}$. 
A

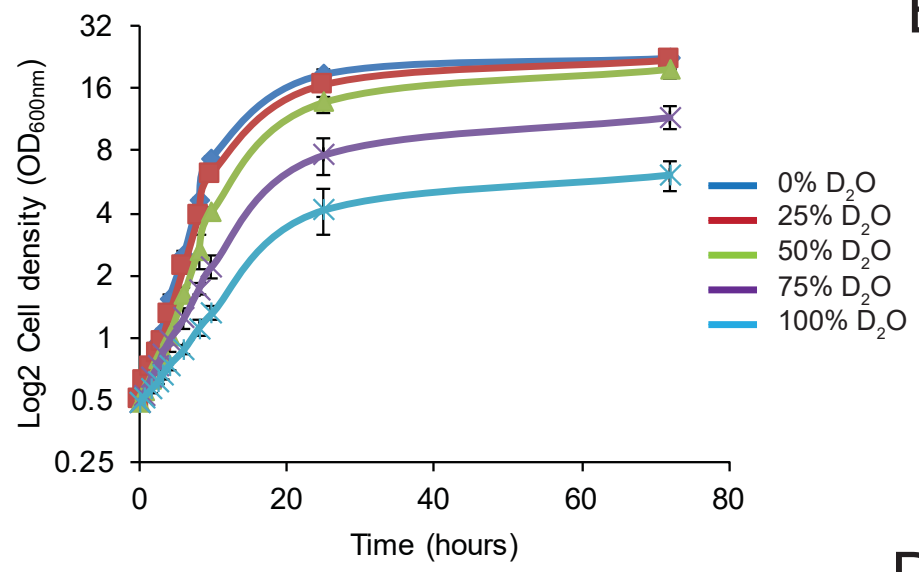

C

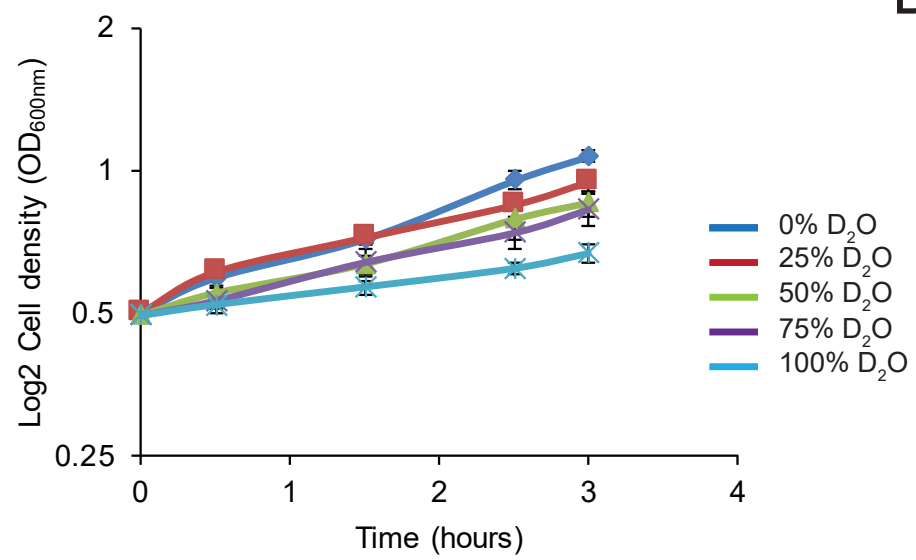

$E$

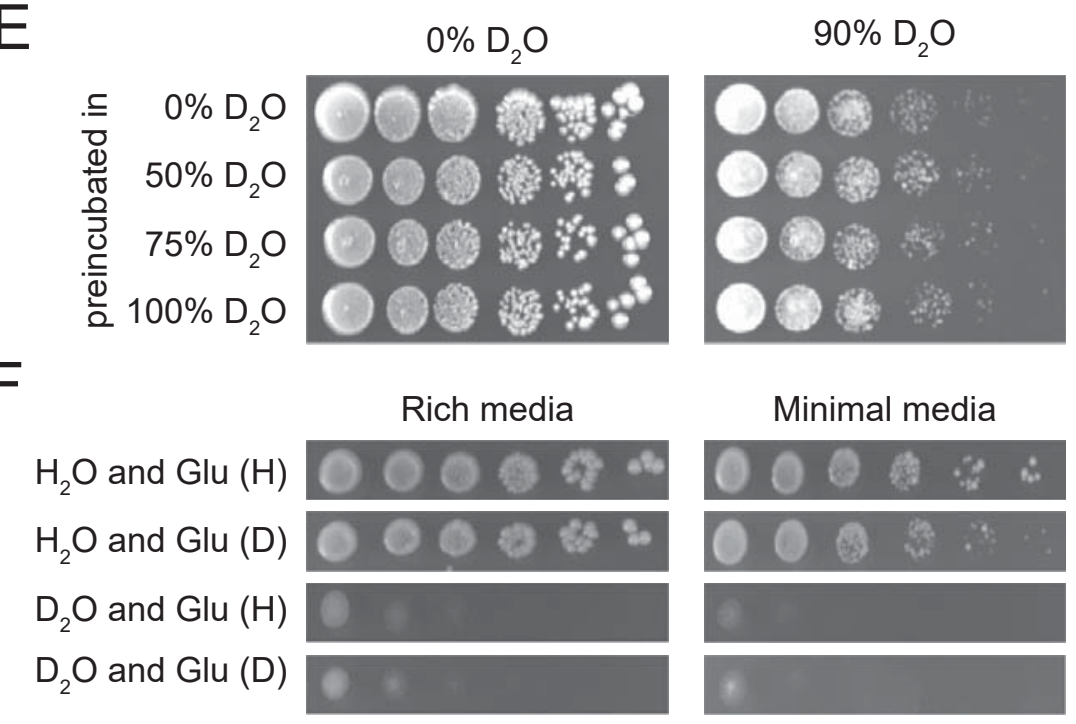

B
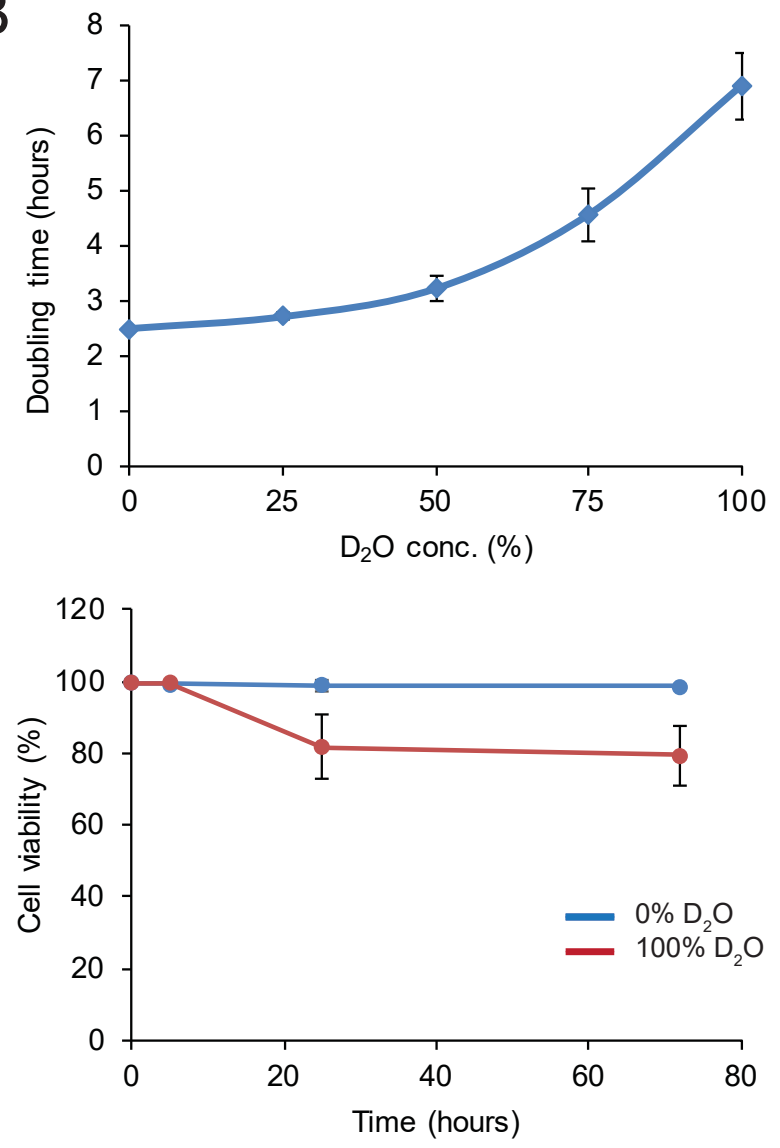

$95 \% \mathrm{D}_{2} \mathrm{O}$

$100 \% \mathrm{D}_{2} \mathrm{O}$

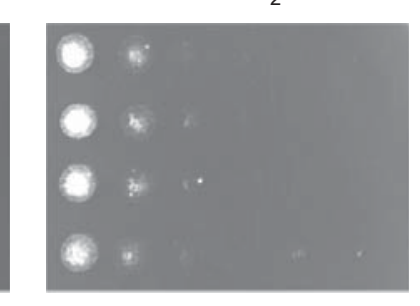

$\mathrm{F}$

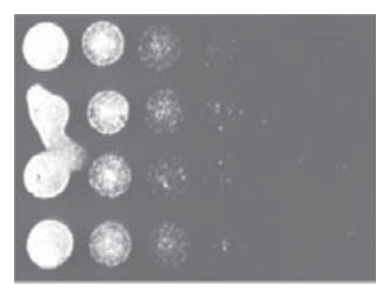


bioRxiv preprint doi: https://doi.org/10.1101/692889. this version posted July 4,2019 . The copyright holder for this preprint (which was not Figure 2 certified by peer review) is the author/funder. It is made available under a CC-BY-NC-ND 4.0 International license.

A

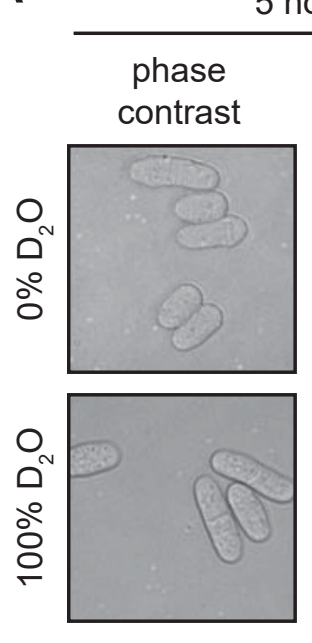

C
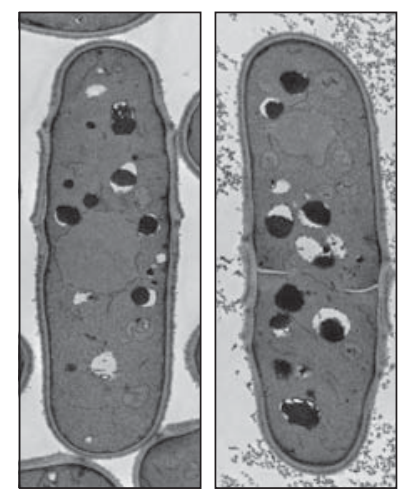

$\mathrm{D}$
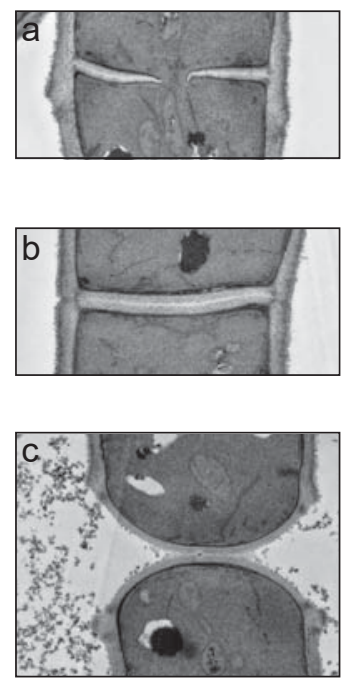

E

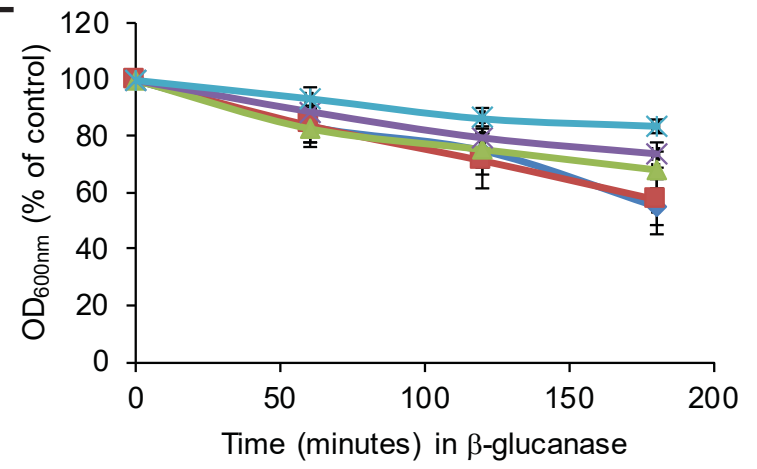

B
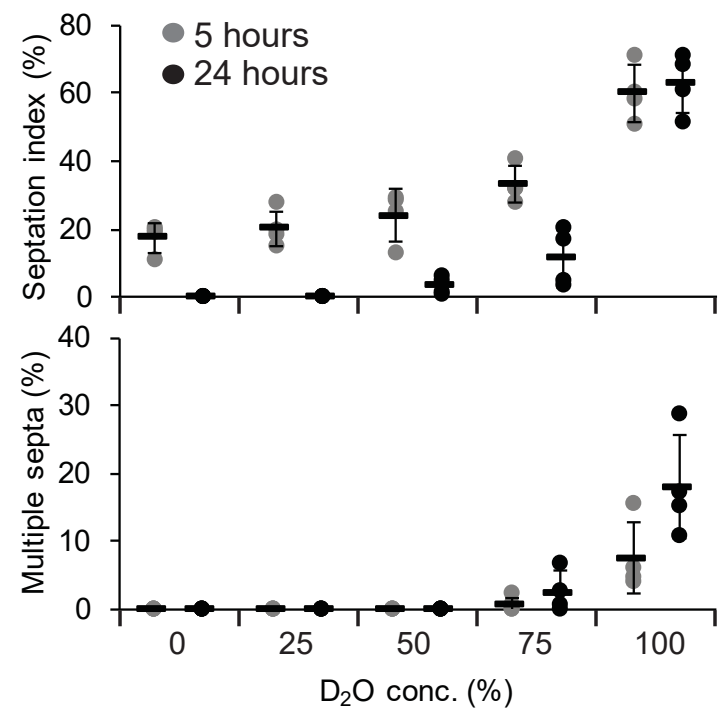

$\mathrm{D}_{2} \mathrm{O}, 24 \mathrm{~h}$
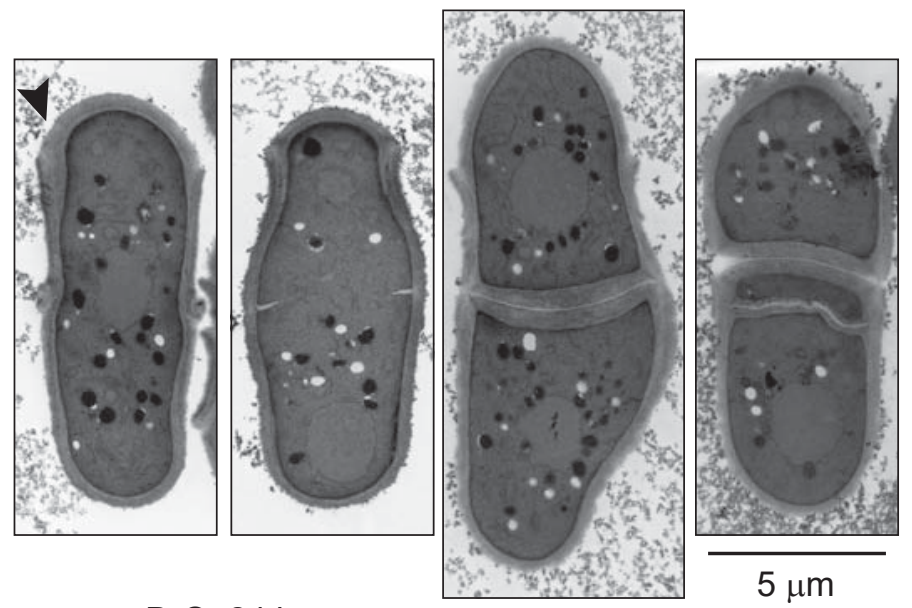

$\mathrm{D}_{2} \mathrm{O}, 24 \mathrm{~h}$
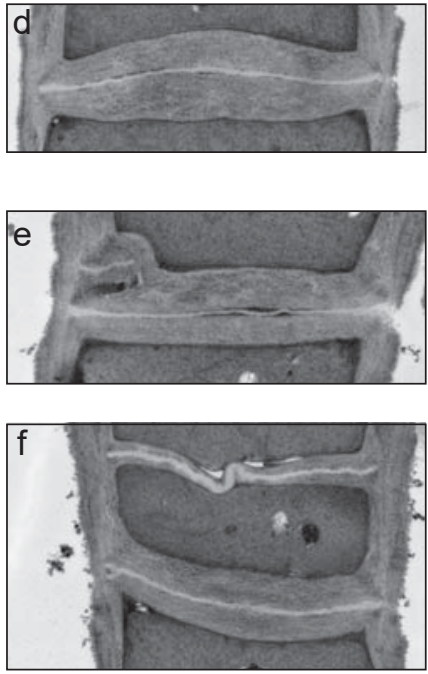
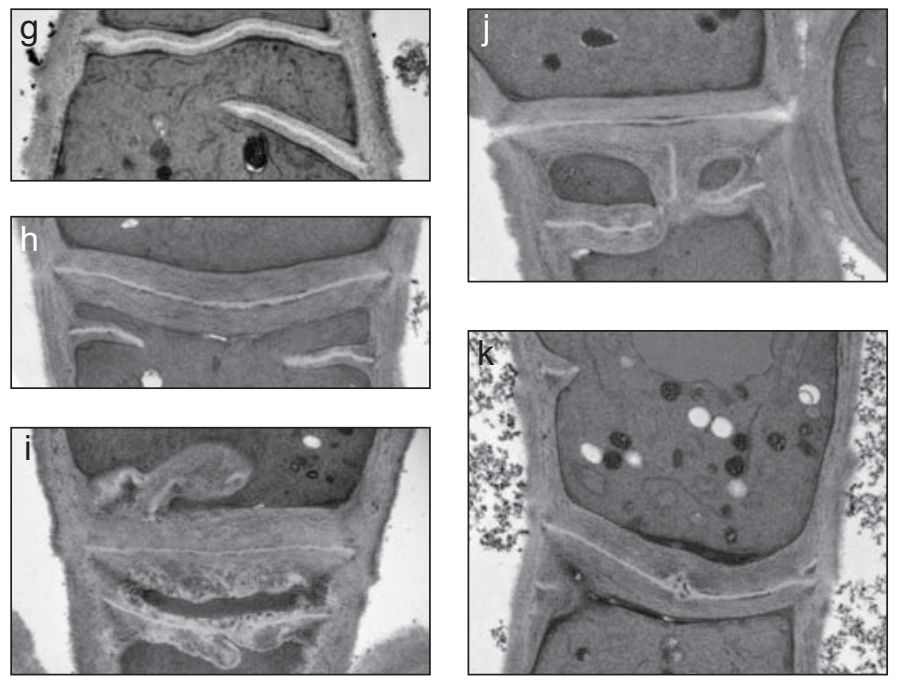

$5 \mu \mathrm{m}$
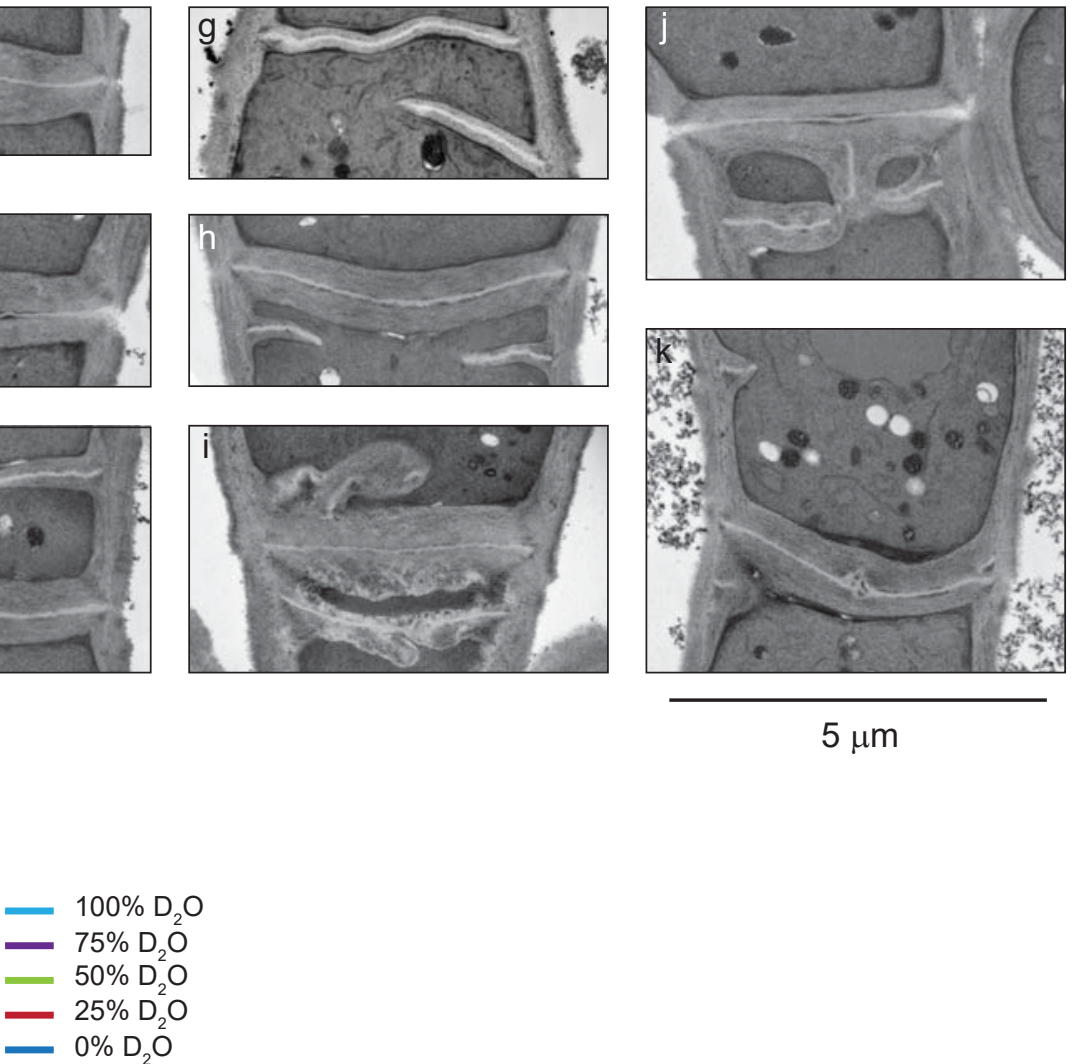
Figure 3

A
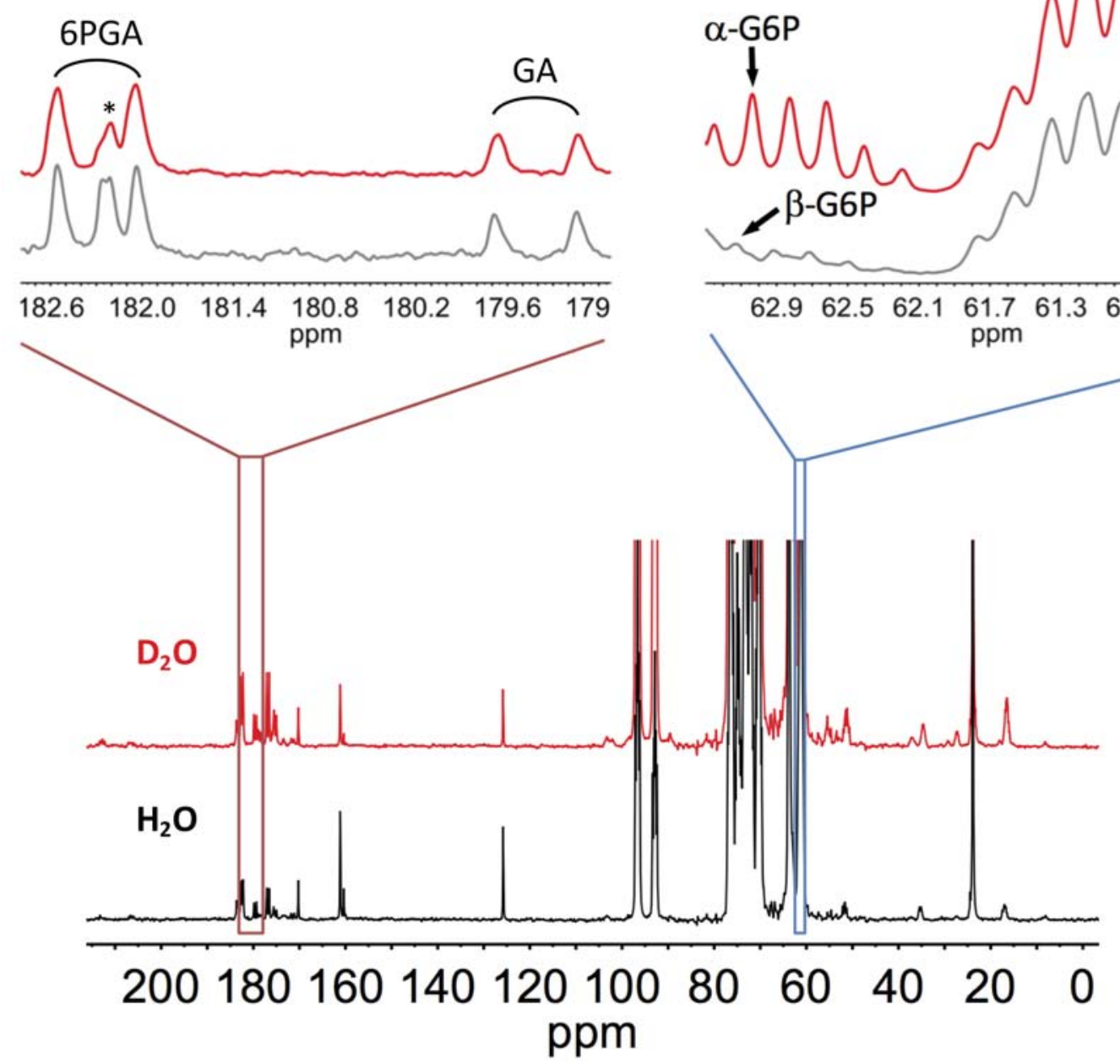

B

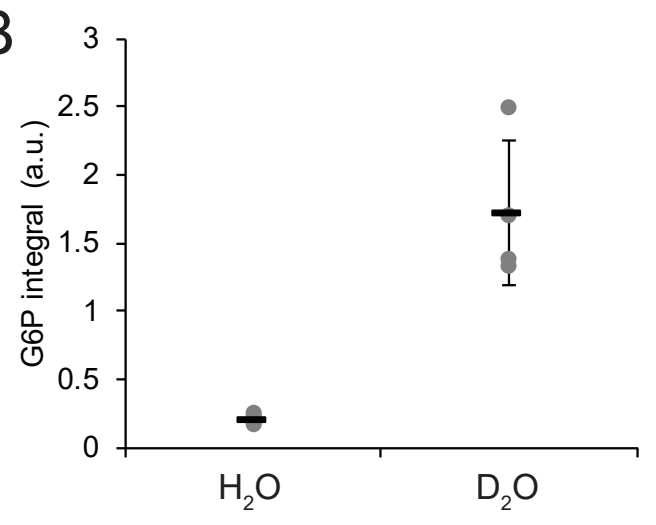

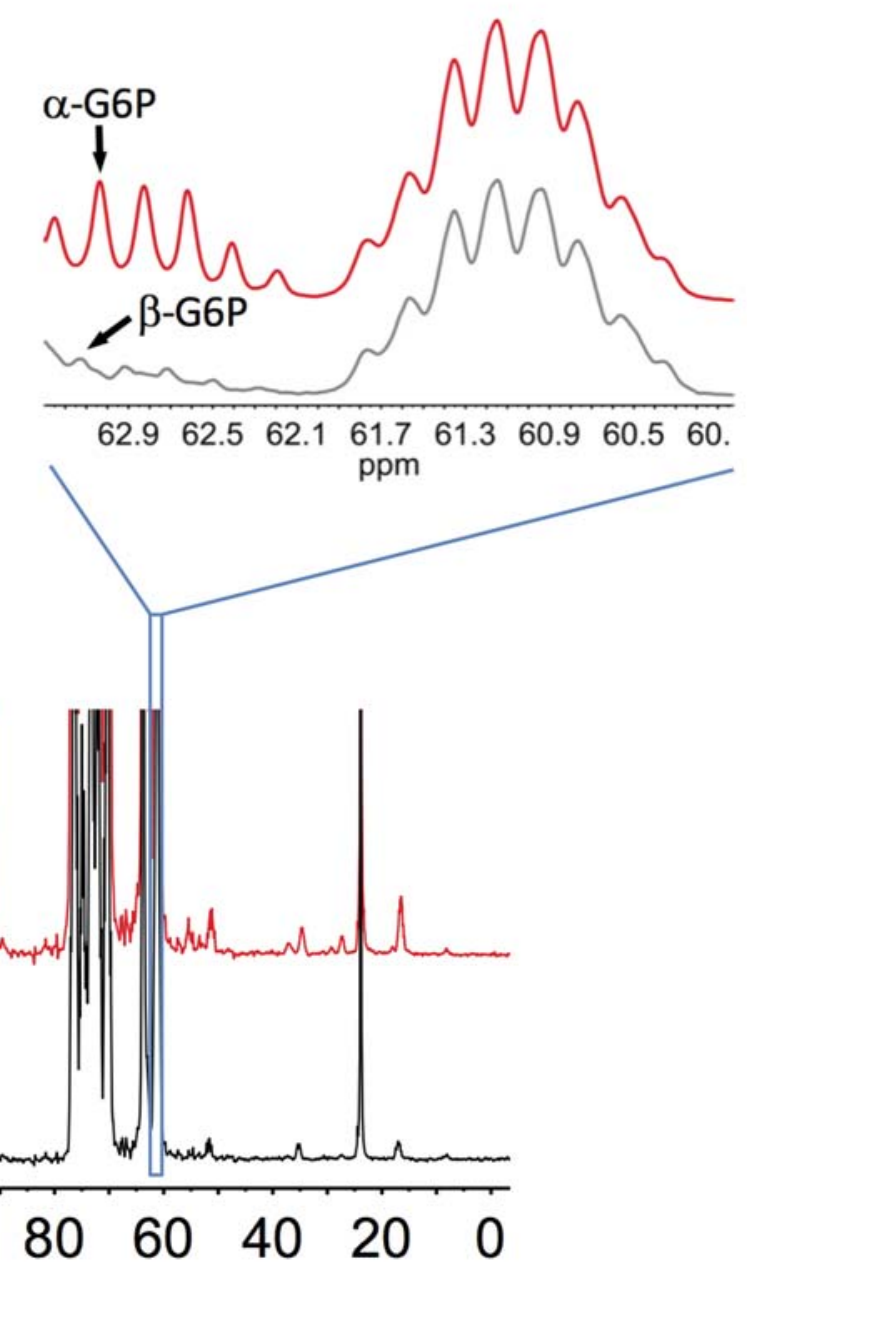

$\begin{array}{llllllll}62.9 & 62.5 & 62.1 & 61.7 & 61.3 & 60.9 & 60.5 & 60 .\end{array}$

C

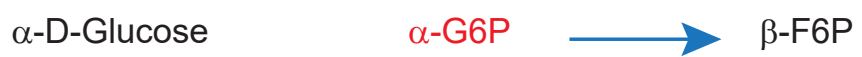


bioRxiv preprint doi: https://doi.org/10.1101/692889. this version posted July 4, 2019. The copyright holder for this preprint (which was not

Figure $4 \quad$ certified by peer review) is the author/funder. It is made available under a CC-BY-NC-ND 4.0 International license.

A
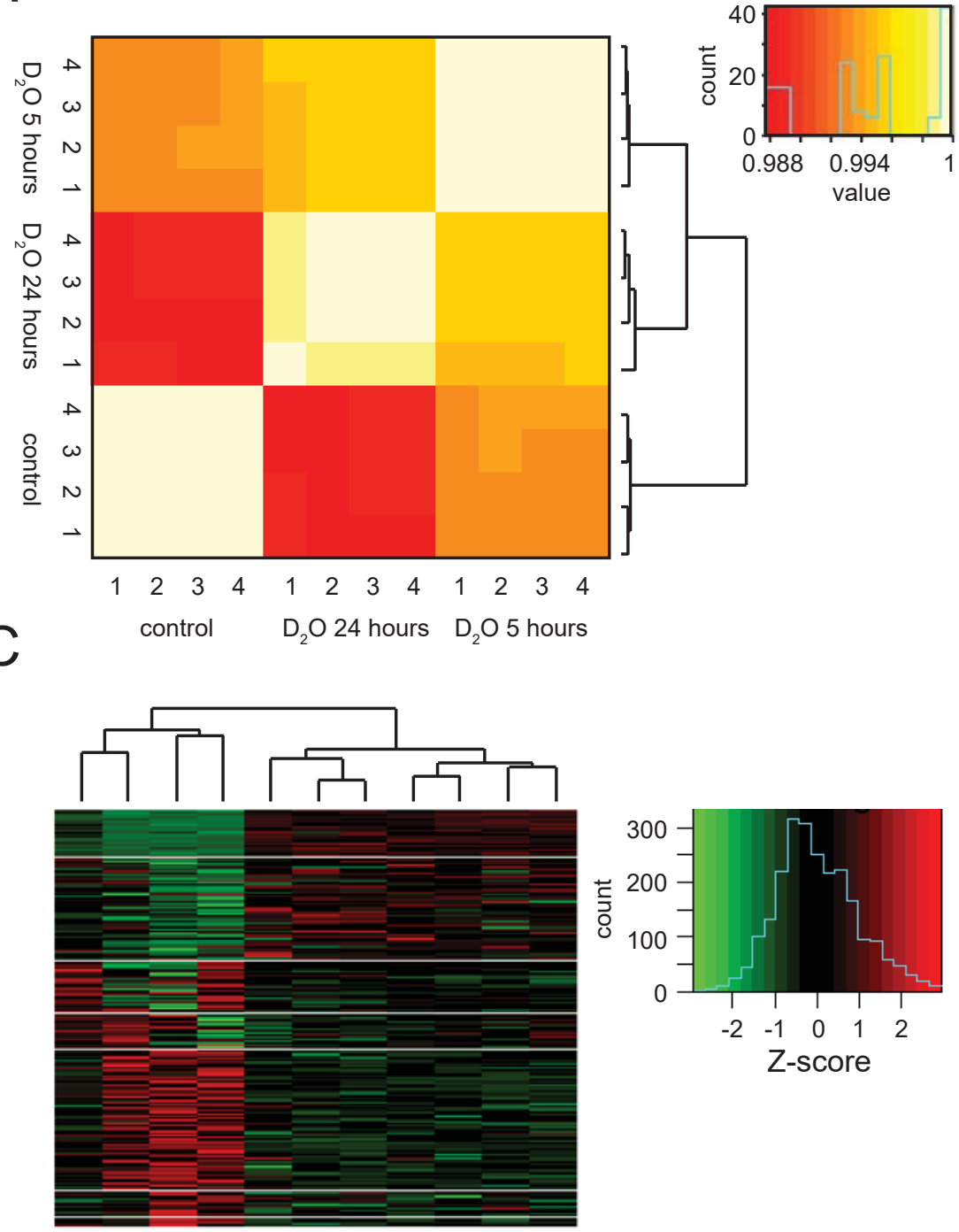

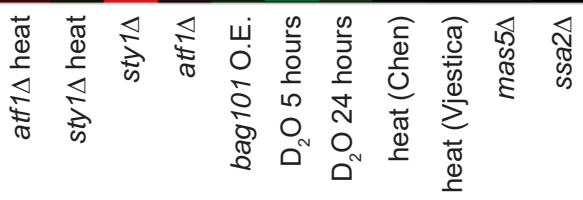

B
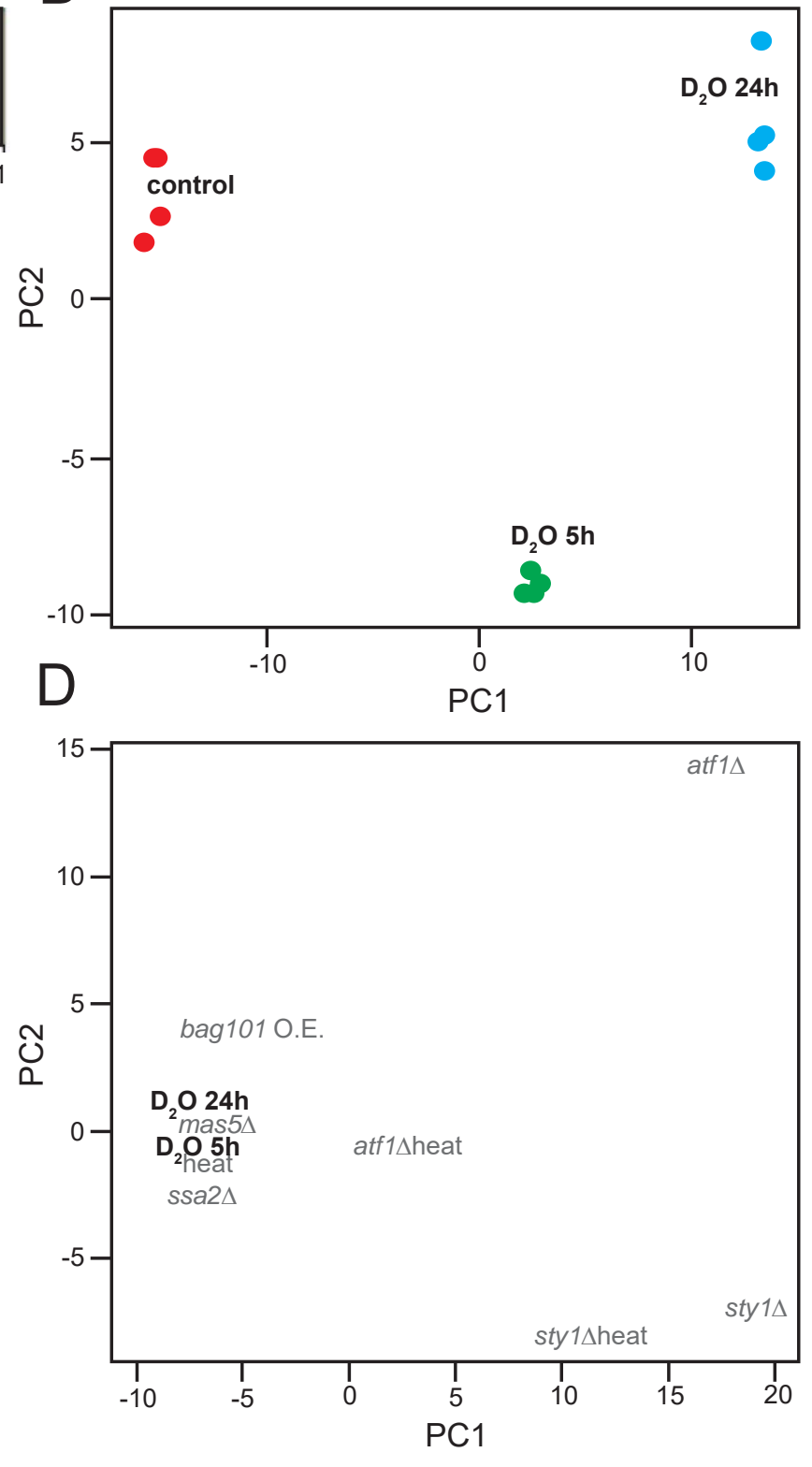

$90 \% \mathrm{D}_{2} \mathrm{O}$

$100 \% \mathrm{D}_{2} \mathrm{O}$

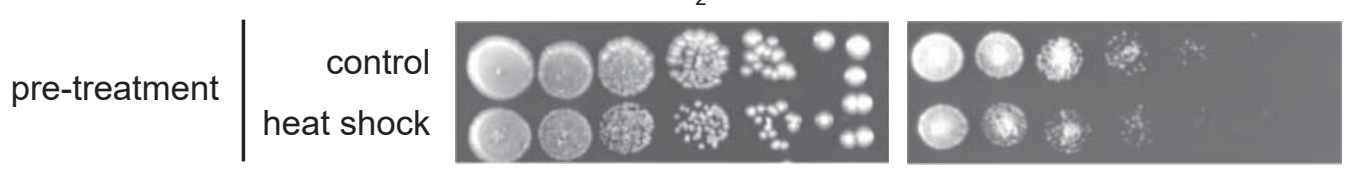

$0 \% \mathrm{D}_{2} \mathrm{O}$

pre-treatment

G

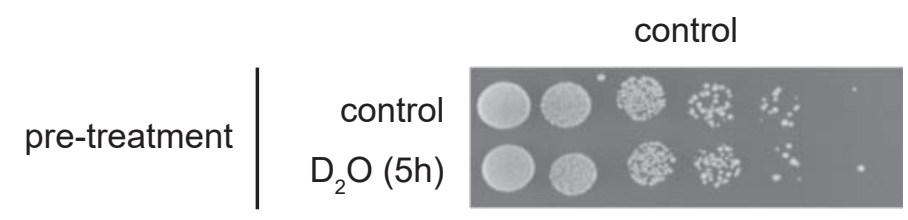

$0 \mathrm{mM} \mathrm{H}_{2} \mathrm{O}_{2}$

\begin{tabular}{l|r} 
pre-treatment & $\begin{array}{r}\text { control } \\
\mathrm{D}_{2} \mathrm{O}(5 \mathrm{~h})\end{array}$
\end{tabular}
$95 \% \mathrm{D}_{2} \mathrm{O}$

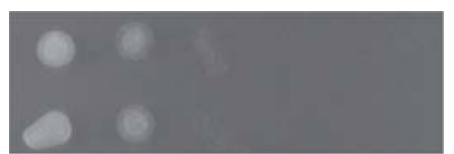

$48^{\circ} \mathrm{C}, 15 \mathrm{~min}$

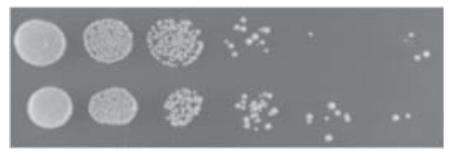

$1 \mathrm{mM} \mathrm{H}_{2} \mathrm{O}_{2}$

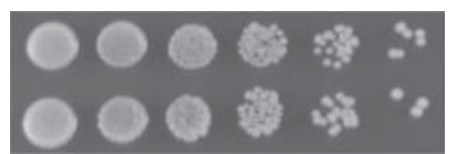

$100 \% \mathrm{D}_{2} \mathrm{O}$

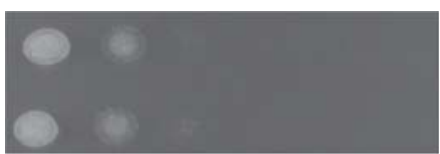

$48^{\circ} \mathrm{C}, 45 \mathrm{~min}$

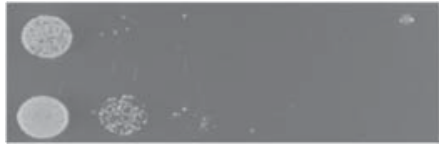

$5 \mathrm{mM} \mathrm{H}_{2} \mathrm{O}_{2}$ 
A

$0 \% \mathrm{D}_{2} \mathrm{O}$

$75 \% \mathrm{D}_{2} \mathrm{O}$

$100 \% \mathrm{D}_{2} \mathrm{O}$

wild type
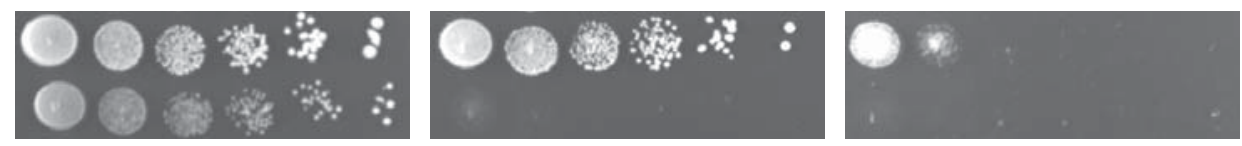

B

$0 \% \mathrm{D}_{2} \mathrm{O}$

$90 \% \mathrm{D}_{2} \mathrm{O}$

$100 \% \mathrm{D}_{2} \mathrm{O}$

wild type
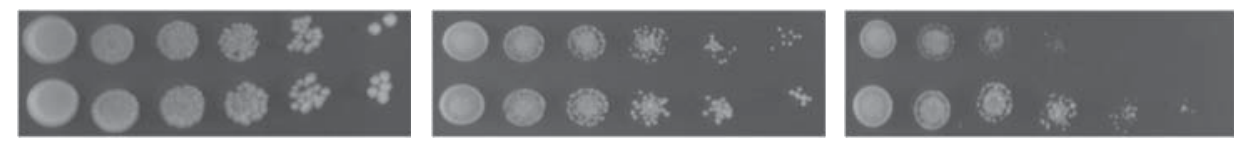

wild type

grx5 5

swd2 $\Delta$

$k s p 1 \Delta$
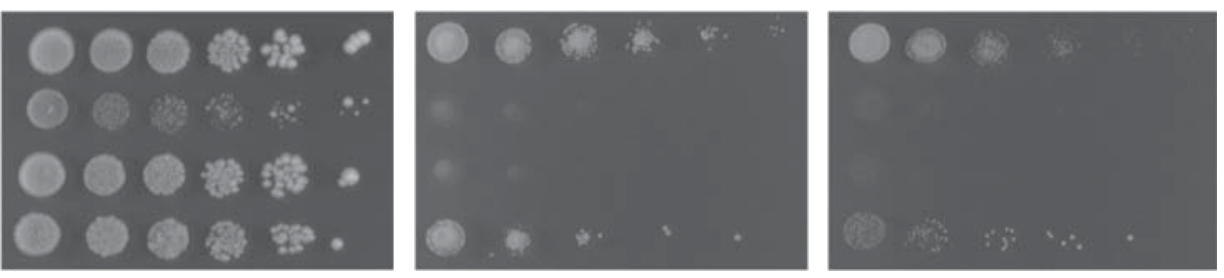

rga7 $\Delta$

rhp41A

cch1 $1 \Delta$

cdr1 $1 \Delta$
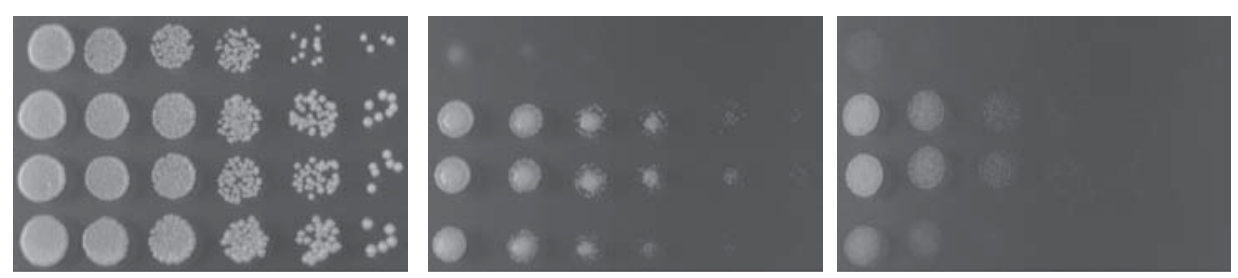

C

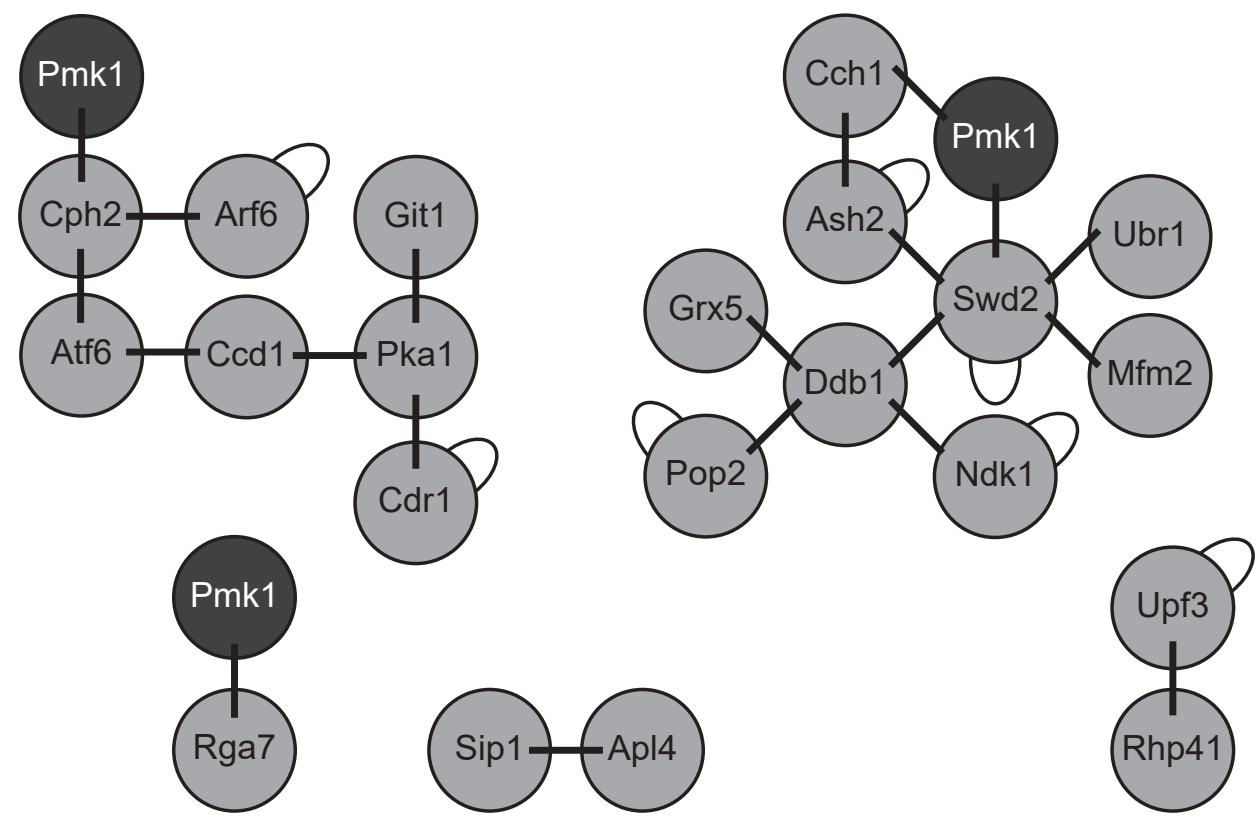


A

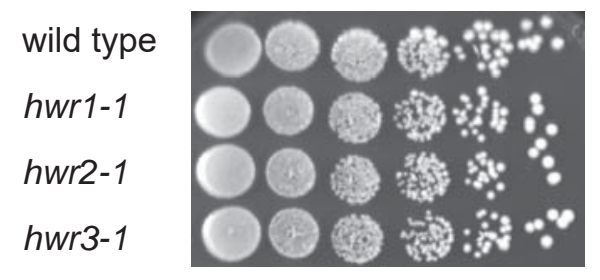

C

$$
0 \% \mathrm{D}_{2} \mathrm{O}
$$
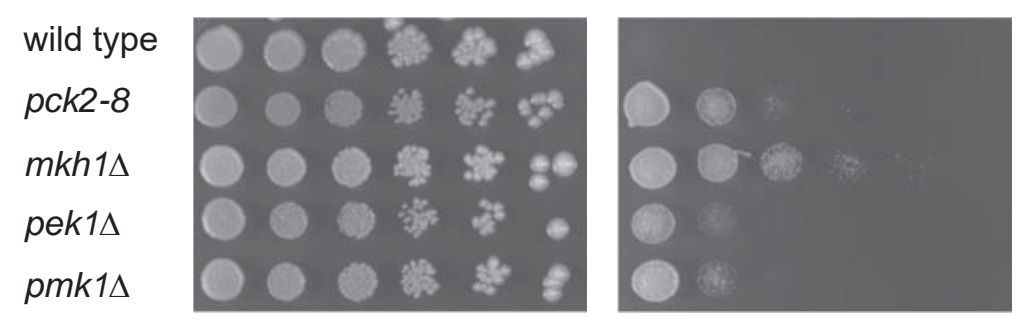

D
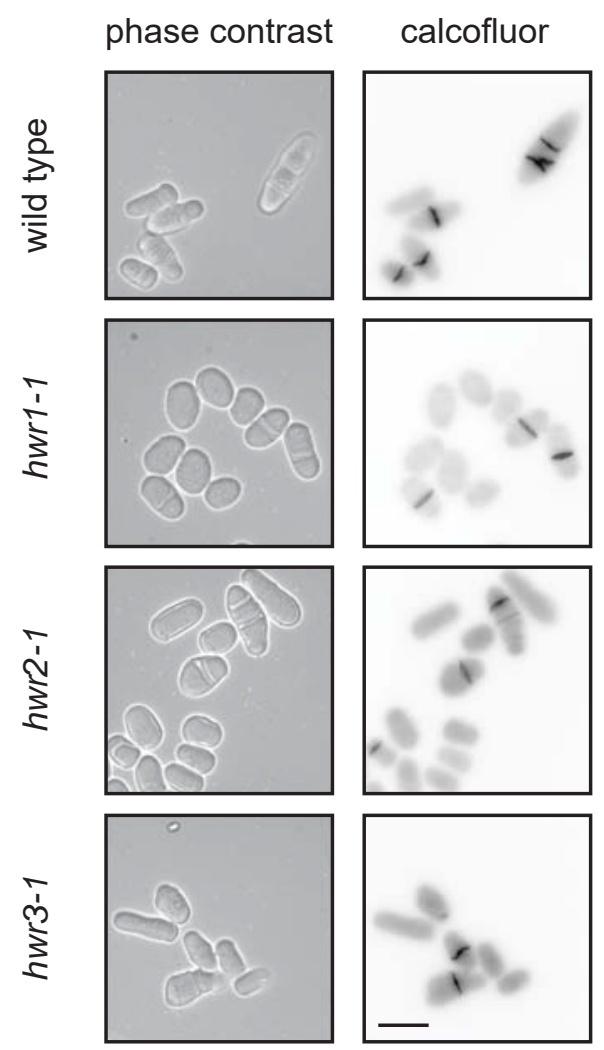

$100 \% \mathrm{D}_{2} \mathrm{O}$

$100 \% \mathrm{D}_{2} \mathrm{O}$
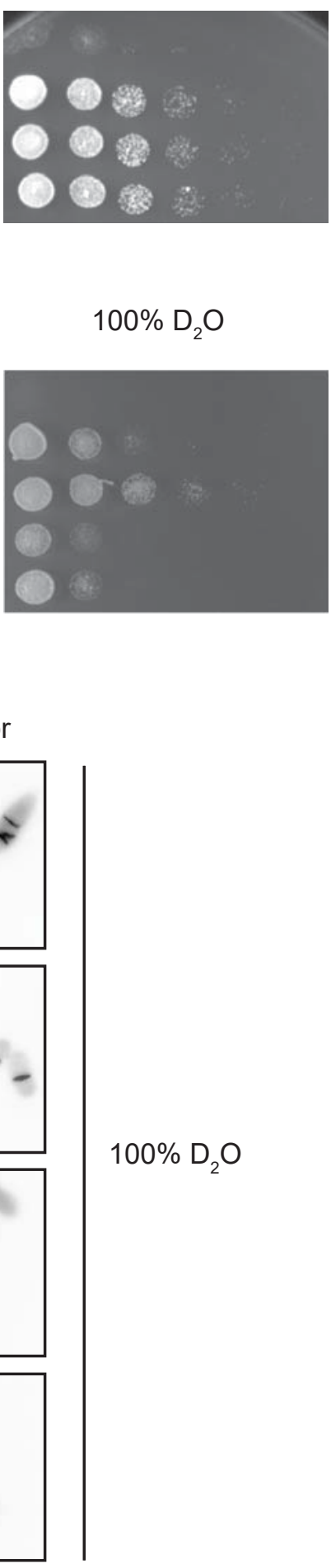

B
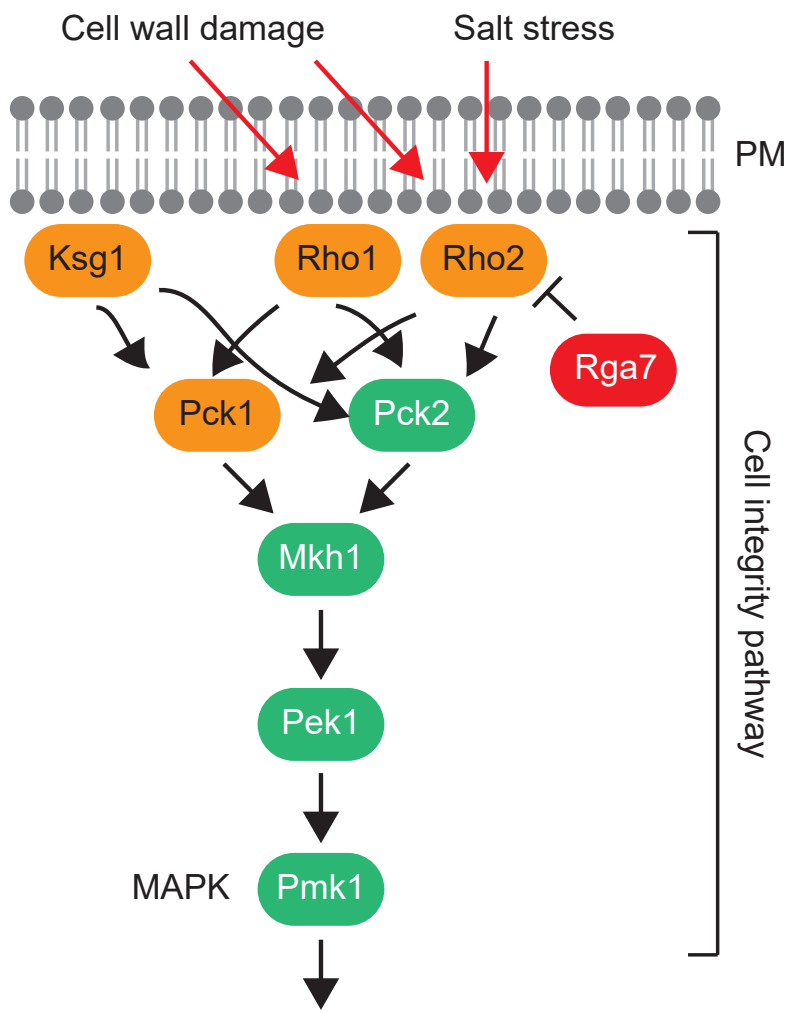

Cell wall synthesis

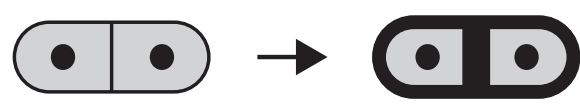

$E$

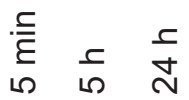

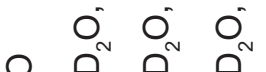

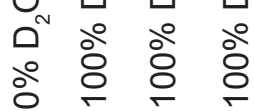

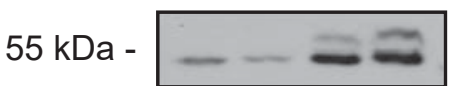

P-p44/42

55 kDa -

HA (Pmk1)

55 kDa -

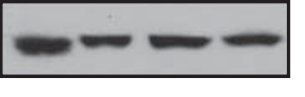

$\alpha$-tubulin

pmk1-HA 